\title{
7 \\ O ART. 146-A DA CONSTITUIÇÃO FEDERAL E O PRINCÍPIO DA NEUTRALIDADE TRIBUTÁRIA
}

Valeria Isis Suzanne Oliveira do Valle

\section{INTRODUÇÃO}

O objetivo deste trabalho é estudar a aplicação do artigo 146-A da Constituição Federal, bem como os princípios correlatos, quais sejam o princípio da neutralidade tributária, a livre concorrência e a igualdade.

Iremos tratar no capítulo 1 sobre a conceituação do princípio da neutralidade tributária. Este princípio almeja uma atuação por parte do Estado que preze pela isonomia dos agentes econômicos no momento em que exerce seu poder de tributar e, por isso, confunde-se com o princípio da igualdade. Contudo, vale ressaltar que colocar os dois princípios - igualdade e neutralidade - como sinônimos não é correto, o que faz surgir a necessidade de termos um critério que os diferencie: a livre concorrência. Enquanto de um lado temos o princípio da igualdade como uma forma de atuar que trate os iguais como iguais e os desiguais como desiguais, na medida das suas diferenças, temos do outro a neutralidade tributária, que possui como objetivo maior o tratamento igualitário no campo da livre concorrência dos agentes. De forma simplificada, o princípio visa proteger o mercado de uma tributação que possa favorecer uns e desfavorecer outros, o que viria a prejudicar o funcionamento normal da concorrência, causando desequilíbrios. Dois agentes que estejam em situação de igualdade fática - as mesmas condições de mercado com as mesmas obrigações tributárias - estão atuando num mercado com concorrência equilibrada. Não poderá a tributação intervir de forma que esse equilíbrio seja prejudicado, aumentando a carga tributária para um e diminuindo para outro. 
•• Tributação, direitos fundamentais e desenvolvimento

Se esses contribuintes são iguais na realidade, não há porque a tributação realizar uma discriminação que faça com que essa igualdade material seja maculada.

Todavia, entender que a tributação não deve ser mais ou menos onerosa para contribuintes em situação de igualdade material não é o mesmo que entender que tributos são puramente neutros. $\mathrm{Na}$ realidade, não existem tributos plenamente neutros porque, de uma forma ou de outra, a tributação irá interferir no mercado e nas condutas dos agentes. $\mathrm{O}$ sistema tributário não é um conjunto de regras dotado de perfeição e nem existe num vácuo, ou seja, não podemos afirmar que os tributos não irão afetar, em algum grau, as condutas que deverão ser tomadas pelos agentes econômicos, já que o custo com a tributação está inserido na equação dos lucros e despesas de uma operação. Tendo isso em vista, a tributação deve ser realizada de forma justa e levando em consideração as realidades em que se encontram os contribuintes. Uma carga tributária que seja excessivamente onerosa ao agente econômico " $x$ " e pouco onerosa ao agente econômico " $y$ " irá, de forma clara, prejudicar o equilíbrio em que esses agentes se encontram. $\mathrm{O}$ agente econômico " $\mathrm{x}$ " terá um custo maior para produzir determinado produto e terá que repassar esse gasto ao valor final, o qual será maior que o valor do produto final do agente econômico "y". Dessa forma, os dois agentes estarão concorrendo de forma desequilibrada por causa de uma tributação discriminatória.

Quando ocorre essa tributação excessiva para um contribuinte que está em situação de igualdade fática e o consequente desequilíbrio da concorrência, surge a necessidade de remediar esse problema de alguma forma. A defesa da concorrência, em outros âmbitos que não o tributário, já é realizada pelo Sistema Brasileiro de Defesa da Concorrência e suas normas que coíbem o abuso de poder por parte dos agentes. $\mathrm{O}$ caso que relatamos, no entanto, não se trata de conduta abusiva por parte do agente econômico, mas sim uma conduta estatal na seara tributária que interferiu no funcionamento correto da livre concorrência. Após a publicação da Emenda Constitucional 42/2003, introduziu-se na Constituição Federal o artigo 146-A, que ficou encarregado de solucionar esse determinado problema concorrencial causado pela tributação.

No capítulo 2, iremos analisar os instrumentos elegidos pelo constituinte derivado para prevenir os desequilíbrios concorrenciais, que serão os critérios especiais de tributação, a serem instituídos por meio de Lei Complementar. Por critérios especiais de tributação, podemos entender uma modificação na estrutura da norma de incidência tributária, ou seja, nos itens que compõem a obrigação tributária, 
como o sujeito passivo, o fato gerador, a base de cálculo ou a alíquota. Pode, por exemplo, ser um critério especial de tributação a antecipação do fato gerador num sistema de tributação em cadeia de produção, o que faz com que seja modificado o contribuinte do tributo por meio da substituição tributária. Esse é apenas um exemplo de um critério especial de tributação, mas o legislador complementar poderá instituir outros critérios que julgar necessários, como a redução da alíquota e até a modificação da forma de fiscalização e recolhimento do tributo. Iremos estudar de forma mais aprofundada os critérios especiais de tributação no capítulo que se preocupa em abordar a estrutura do artigo 146-A.

A escolha do constituinte derivado pela Lei Complementar possui uma razão: por meio dessa lei, é possível que o legislador atinja todos os entes - Estados, Distrito Federal e Municípios - e mantenha uma uniformidade de critérios especiais de tributação. Não seria razoável que cada ente da Federação ficasse encarregado de criar sua lei instituindo critérios de modificação da norma tributária, porque não somente seriam leis em excesso, mas como também seriam mais desagregadoras do que agregadoras e poderiam causar uma guerra fiscal. A ideia por trás da Lei Complementar aludida no artigo 146-A, CRFB/88, é criar critérios especiais de tributação que sejam nacionais e iguais para todos os entes, de tal forma que não fomente tensões entre Estados, o Distrito Federal e os Municípios. A escolha da Lei Complementar foi acertada, uma vez que sua aprovação exige requisitos mais rigorosos de quórum, o que acarretaria numa maior discussão acerca de seu conteúdo, já que teria impactos sobre o território nacional como um todo.

A Lei Complementar aludida no artigo em discussão ainda não existe, mas foram criados projetos de Lei Complementar com o intuito de suprir essa necessidade de estabelecer critérios especiais de tributação para remediar distúrbios concorrenciais. Por isso, no capítulo 3 deste trabalho iremos estudar dois projetos, um de 2011 e outro de 2013, cada um com o estabelecimento de critérios que seus legisladores consideraram adequados para lidar com uma situação de desequilíbrio concorrencial.

O Projeto de Lei de 2011 propôs a criação de uma CIDE, uma contribuição que permite a União intervir sobre o domínio econômico para prevenir que ocorram possíveis distúrbios concorrenciais causados pela tributação. Dentre as situaçōes em que a CIDE poderá incidir sobre, podemos destacar aquelas nas quais os bens e serviços prestados por uma empresa esteja dominando o mercado de tal forma que, por si só ou por intermédio de condutas abusivas, cause danos ao fun- 
•• Tributação, direitos fundamentais e desenvolvimento

cionamento do mercado e aquelas em que a empresa teve concessão irregular de benefício fiscal. $\mathrm{O}$ destaque para tais situações dá-se por conta da explicação que fizemos anteriormente: no momento em que uma atuação do Estado, dentro do seu exercício de competência tributária, causa desequilíbrios na concorrência, faz-se necessária uma solução que, no caso desse Projeto de Lei, foi a instituição de uma CIDE.

Do outro lado, o Projeto de Lei de 2013 propôs critérios especiais de tributação que envolvem a antecipação do fato gerador, o regime especial de fiscalização e apuração de tributos, a suspensão ou cassação do registro especial de funcionamento das empresas cujas atividades estão sujeitas à autorização governamental, dentre outros. A solução proposta por esse Projeto de Lei difere significativamente do outro projeto, uma vez que seus critérios especiais de tributação estão diretamente vinculados à estrutura da norma tributária - inclusive com a utilização da substituição tributária - e também às obrigações acessórias, que nada mais são que deveres instrumentais a serem cumpridos pelos contribuintes da obrigação principal. Não somente modificou a estrutura da norma de incidência, mas também formas diferenciadas para que a administração tributária possa atuar de forma direta na defesa da livre concorrência.

Em suma, o trabalho irá dedicar-se ao estudo dos efeitos negativos que uma conduta não isonômica do Estado, quando exerce sua competência tributária, pode causar à livre concorrência e, por consequência, ao princípio da igualdade. Também estudaremos a forma de remediação desses desequilíbrios concorrenciais proposta pelo artigo 146-A da CRB/88 e os seus critérios especiais de tributação.

\section{O PRINCÍPIO DA NEUTRALIDADE TRIBUTÁRIA}

\subsection{O princípio da neutralidade tributária como subprincípio da igualdade e sua relação com a livre concorrência}

Antes de adentrarmos no conceito do princípio da neutralidade tributária, precisamos abordar outros temas que tangenciam a construção do seu significado. Neste sentido, vamos entender inicialmente o que são os princípios limitadores do poder de tributar, quais são os princípios que envolvem a Ordem Econômica protegida pela Constituição Federal, destacar a livre concorrência como nosso objeto de estudo dentro dos princípios que envolvem a Ordem Econômica e entender o funcionamento do princípio da igualdade em relação à neutralidade tributária. 


\subsubsection{Limitações ao poder de tributar}

Para podermos entender a função do princípio da neutralidade tributária, é necessário abordar o funcionamento dos princípios limitadores ao poder de tributar, uma vez que eles servem como verdadeiros balizadores da competência tributária dos entes federativos.

As limitações ao poder de tributar podem ser divididas em: (1) princípios constitucionais tributários e (2) imunidades tributárias. São limitações presentes na Constituição Federal na seção "Limitações do Poder de Tributar", mas que também podem estar fora desta seção, permeando todo o sistema tributário constitucional ou até em outros capítulos da Constituição, como é o caso do capítulo da Ordem Econômica.

Entretanto, as limitações não estão somente presentes na Constituição Federal, tendo em vista que o constituinte abriu a possibilidade de outros tipos normativos, como o caso da lei complementar, convênios e resoluções, também servirem de balizadores do poder legislativo na seara tributária, seja no momento da criação de um tributo, seja quando for necessária sua modificação. É uma verdadeira forma de delimitação da competência do poder de tributar, de tal forma que a tributação ocorra respeitando preceitos fundamentais do sujeito que será designado para realizar o pagamento o tributo.

Dessa forma, o exercício do poder de tributar deve estar em conformidade com os princípios constitucionais tributários e, quando for o caso, adequar-se a critérios quantitativos definidos pela Constituição, lei complementar ou em resoluções do Senado (os limites de alíquota máxima e mínima). Luciano Amaro nesta seara conceitua as limitaçôes ao poder de tributar:

(...) integram o conjunto de traços que demarcam o campo, o modo, a forma e a intensidade de atuação do poder de tributar (ou seja, do poder, que emana da Constituição, de os entes políticos criarem tributos. ${ }^{1}$

A conceituação feita pelo tributarista vai ao encontro com o que dissemos anteriormente: é um molde para que a atuação do Estado, no momento em que exerce seu poder de tributar, não seja causadora de uma violação de direitos do contribuinte, para que a tributação não gere insegurança jurídica, perfazendo-se, portanto, em um ato legítimo.

AMARO, Luciano. Direito tributário brasileiro. 19. ed. São Paulo: Saraiva, 2013, p. 129. 
•• Tributação, direitos fundamentais e desenvolvimento

\subsubsection{A Ordem Econômica na Constituição Federal de 1988 e a livre concorrência}

A Ordem Econômica na Constituição de 1988 caracteriza-se como um conjunto de normas que visam fazer com que as relaçôes econômicas estejam adequadas a um regime jurídico para garantir que produzam resultados desejados socialmente. $\mathrm{O}$ artigo 170 traça quais são os princípios norteadores dessa Ordem Econômica, quais sejam: soberania nacional, propriedade privada, função social da propriedade, livre concorrência, defesa do consumidor, defesa do meio ambiente, redução das desigualdades regionais e sociais, busca do pleno emprego, tratamento favorecido para empresas de pequeno porte que tenham sido constituídas no Brasil ou, em caso contrário, tenham sede e administração no País, e livre iniciativa ${ }^{2}$.

Para que essas relações estejam em conformidade com os resultados almejados, o constituinte atribuiu ao Estado poderes para intervir, por meio da regulação de condutas, sobre o domínio econômico sempre que a tutela se mostrar necessária. Ocorrida uma violação de um princípio que esteja presente na Ordem Econômica, como é o caso da livre concorrência, poderá o Estado, protegido pela Constituição, intervir de forma que essa violação cesse.

Dentre os princípios que norteiam a Ordem Econômica, iremos destacar como objetivo maior de estudo do trabalho a livre concorrência, que está no inciso IV do artigo 170, CRFB/88. A existência desse princípio está ligada à ideia de que as relações econômicas entre os agentes devem ocorrer de forma harmoniosa, sem distorção na dinâmica do mercado. Em outros termos, os agentes que atuam no mercado devem estar em posição de igualdade de competição entre si, o que significa dizer que são tratados sem quaisquer discriminações e podem, dessa forma, ofertar um produto da melhor qualidade e com o menor preço que conseguirem. Trata-se de um princípio instrumental, uma vez que seu condão é o de fornecer um mercado equilibrado para que sejam alcançados os demais princípios assegurados pelo constituinte. Vinícius Alberto Rossi Nogueira conceitua o princípio da livre concorrência da seguinte forma:

(...) uma exigência, constitucionalmente qualificada, de equilíbrio nas forças econômicas atuantes no mercado de modo que a alocação dos recursos nacionais seja a mais próxima possível daquela socialmente desejável. ${ }^{3}$

BRASIL. Constituição (1988). Constituição da República Federativa do Brasil. Brasília, Distrito Federal: Senado, 1988. Art. 170.

3 NOGUEIRA, Vinícius Alberto Rossi. Direito tributário e livre concorrência: da interpretação e aplicação do artigo 146-A da Constituição Federal artigo 146-A da Constituição Federal. São Paulo, Universidade de São Paulo, 2014, p. 40. Tese (Mestrado em Direito) - Programa 
Analisando o conceito acima destacado, percebemos que a livre concorrência se correlaciona com a igualdade. Vincula uma exigência de que o Estado deve se encarregar de coibir atitudes monopolistas no mercado por parte de seus agentes e, dessa forma, propiciar um ambiente estável para que os outros princípios da Ordem Econômica possam ser exercidos. A neutralidade tributária é inerente à livre concorrência, porque este é o critério que dá característica àquela e diferencia neutralidade de igualdade, já que os dois princípios não devem ter uma mesma conceituação.

Com a análise dessas explicitações, podemos observar que a livre concorrência pode funcionar em dois aspectos na norma tributária: (1) justificativa, quando a norma almejará corrigir falhar de mercado, ou seja, que a norma tributária terá como objetivo a manutenção de um mercado sadio com concorrência equilibrada, (2) limitação, que é o caso do artigo 146-A, CRFB/88, quando a norma objetiva evitar que a própria norma tributária desequilibre a concorrência.

Quando falamos em justificativa para a norma tributária, é importante ressaltarmos que isso significa dizer que deve existir uma razão para que esta norma afete indivíduos "x" e não indivíduos " $y$ ", pois isto vai ao encontro da promoção da própria igualdade, já que a discriminação deve ser fundamentada com critérios razoáveis, conforme vamos explicitar quando tratarmos do princípio da igualdade. As normas tributárias indutoras encontram sua razão de existir nos próprios princípios da Ordem Tributária, mas também podem encontrar suas fundamentações em outros princípios constitucionais, como é o caso da livre concorrência que, conforme afirmamos anteriormente, é um princípio defendido pela Constituição Federal no capítulo da Ordem Econômica, em seu artigo 170.

Luís Eduardo Schoueri conclui:

Terá tal caráter a norma que agravar a tributação em mercados pouco competitivos, ou que reduzir a carga tributária de mercados cujo acesso seja restrito. Assim, por exemplo, a norma tributária que incentiva o pequeno empresário, além de obedecer a princípio específico da Ordem Econômica, também busca reduzir barreiras de acesso ao mercado, favorecendo o ambiente de concorrência. Os tributos aduaneiros também servem de excelente instrumento para assegurar a livre concorrência. Da mesma maneira, poder-se-ia imaginar alguma forma de tributação mais gravosa de operações de aquisição de controle, bem como fusōes e incorporação que implicassem atos de concentração. ${ }^{4}$

de Mestrado em Direito Financeiro, Econômico e Tributário, Universidade de São Paulo, São Paulo, 2014. Disponível em: <http://www.teses.usp.br/teses/disponiveis/2/2133/tde-21012015084157/>. Acesso em: 30 jun. 2015.

4 SCHOUERI, Luís Eduardo. Livre concorrência e tributação. Grandes Questôes Atuais do Direito Tributário, Coordenador: Valdir de Oliveira Rocha. São Paulo: Dialética, 2007, 11º volume, p. 252-253. 
-. Tributação, direitos fundamentais e desenvolvimento

A fomentação da livre concorrência por meio da tributação ocorre quando a norma leva os agentes econômicos, por meio de estímulo, a praticarem condutas que incrementem a concorrência dentro do mercado. A modificação de um dos elementos da norma tributária - por exemplo, a redução de uma alíquota - pode proporcionar uma mudança no comportamento do agente de tal forma que ele passe a concorrer de forma melhor dentro do mercado em que anteriormente não possuiria qualquer chance. De outro lado, como Schoueri menciona na citação, uma tributação mais onerosa para quem conduz seus negócios almejando concentrar mercado também vai afetar essas decisões de concentração, o que de forma clara irá afetar a livre concorrência naquele mercado. É possível notar que, independente de qual for a modificação na estrutura da norma tributária, a justificativa de sua existência é a mesma: assegurar o exercício da livre concorrência.

\subsubsection{O princípio da igualdade}

Um dos princípios que se mostram mais importantes para alcançar uma tributação justa é a igualdade ou isonomia, que exige que a lei não discrimine os contribuintes que estão na mesma situação jurídica e discrimine os que não estão em situação jurídica equivalente, levando em conta o grau de sua desigualdade, conforme está presente no artigo 150, II, CRFB/88. Isso importa dizer que toda e qualquer pessoa que esteja enquadrada na hipótese presente na lei estará sujeita a esse mandamento legal. Em suma, numa visão simplificada, todos seriam iguais perante a lei e o aplicador da norma não poderá diferenciar pessoas que estão numa mesma situação jurídica, ora submetendo-as à aplicação da lei, ora isentando-as. Este princípio possui o condão de garantir que o indivíduo não sofra discriminação, seja por perseguições ou favoritismos, por parte do legislador ao instituir uma norma tributária.

A isonomia, em seu aspecto geral, pode ser entendida de três formas diferenciadas conforme Anacleto de Oliveira Farias:

1. Nominalista: de acordo com esse ponto de vista, a ideia de que os homens são todos iguais é falsa, porque a realidade se opera de maneira diferente.

FARIA apud BRAZUNA, José Luis Ribeiro. Defesa da livre concorrência e tributação - à luz do artigo 146-A da Constituição. São Paulo, Universidade de São Paulo, 2009. Tese (Mestrado em Direito) - Programa de Mestrado em Direito Financeiro, Econômico e Tributário, Universidade de São Paulo, São Paulo, 2009, p. 71. 
2. Idealista: essa corrente defende que a igualdade absoluta deve ser sempre perseguida, com o intuito de eliminar desigualdades de ordem social.

3. Realista: entende que as desigualdades individuais são naturais, mas que se deve pregar a igualdade do ser humano em termos universais, garantindo os direitos mais básicos.

Tendo em vista esses posicionamentos, foi inserida na Declaração Universal dos Direitos Humanos o conceito de que homens e mulheres possuem direitos iguais, entendido como a igualdade jurídico-formal, que visa abolir privilégios, regalias concedidas a quem possui uma determinada classe e isençóes pessoais. A igualdade formal leva à ideia de justiça formal, a qual não modifica a realidade de quem se encontra na situação de desigualdade. Com base nesse entendimento, foi cunhado o termo igualdade social, presente nas Constituições da República de Weimar e da Itália pós-guerra. $\mathrm{O}$ conceito de igualdade social envolve não somente a igualdade formal, mas também meios de os indivíduos que vivem na desigualdade participarem no bem-estar social, fazendo com que a igualdade no plano da realidade seja alcançada.

Uma das formas de se alcançar essa igualdade social é por meio de leis que, embora possuam teor discriminatório, visam atingir um grupo social que vive na desigualdade, porque, desta forma, é possível alcançar uma justiça social. A igualdade deve ser vista como um conceito compatível com a discriminação, mas não com a arbitrariedade. No entanto, é importante ressaltar que essa discriminação deve obedecer a dois outros princípios: a razoabilidade e a proporcionalidade. Isso significa dizer que a ação discriminatória deve ser adequada ao objetivo que se propõe, necessária para a realização desse objetivo e não haver nenhum outro meio para se chegar a esse objetivo.

A isonomia tributária, por sua vez, já se encontrava presente no artigo 13 na Declaração dos Direitos do Homem e do Cidadão:

Art. 13 Para a manutenção da força pública e para as despesas da administração, uma contribuição comum é indispensável: ela deve ser igualmente repartida entre todos os cidadãos, de acordo com suas faculdades. ${ }^{6}$ (grifo nosso)

$\mathrm{Na}$ Constituição pátria, não bastou apenas o artigo $5^{\circ}$ para estabelecer a igualdade, sendo necessário o artigo 150, inciso II, conforme citamos anteriormente.

FRANÇA. Declaração dos Direitos do Homem e do Cidadão, 1776. Disponível em: <http:// pfdc.pgr.mpf.mp.br/atuacao-e-conteudos-de-apoio/legislacao/direitos-humanos/declar_dir_ homem_cidadao.pdf $>$. Acesso em: mar. 2016. 
•• Tributação, direitos fundamentais e desenvolvimento

O inciso do referido artigo veda a instituição de tratamentos desiguais entre os contribuintes que se encontrem em situaçôes iguais, seja por conta de ocupação profissional, função exercida ou denominação jurídica de rendimentos, títulos ou direitos. Além disso, o inciso I do artigo 150, artigo 152 e artigo 173, inciso II e $\$ 2^{\circ}$ da Constituição Federal da República Federativa do Brasil estabelecem outras situações em que é vedado o tratamento desigual.

Apesar das vedações citadas, essa igualdade tributária é relativa, o que significa que podem ocorrer discriminações na seara tributária, contanto que sejam situações autorizadas pelo próprio constituinte. Essas discriminações devem possuir um propósito: realizar princípios constitucionais, inclusive a própria igualdade material. Todavia, é necessário que exista sempre um critério de comparação entre os contribuintes. $\mathrm{O}$ emprego do tratamento isonômico deverá ocorrer a partir da adoção, por meio de lei, de critérios que podem ser usados para comparar a igualdade entre os contribuintes. Tais critérios devem ser adequados e coerentes com os princípios constitucionais e tributários. A existência desse critério de comparação garante que não haverá arbítrio e, consequentemente, uma violação ao próprio princípio da igualdade. Como critérios de discriminação válidos, podemos citar a capacidade contributiva, a essencialidade, o destino ao exterior, o uso da propriedade segundo sua função social, a localização e o uso do imóvel, o ato cooperativo etc. ${ }^{7}$.

Para que ocorra o tratamento tributário diferenciado, este deve ser feito de forma razoável, baseando-se num critério discriminatório que identifique diferenças entre as pessoas ou objetos tributados, e ter nexo de causalidade entre o objetivo que se almeja e a discriminação que será feita ${ }^{8}$. Nesse contexto, a capacidade contributiva pode ser enxergada como o critério mais importante para guiar um tratamento tributário isonômico, além de figurar como um princípio limitador do poder tributário. A capacidade contributiva decorre do princípio da igualdade e é fundamental para a aplicação da justiça fiscal, embora Marco Aurélio Greco entenda ao contrário, que a capacidade contributiva não decorre da igualdade, uma vez que, antes de tudo, é necessário verificar a existência de capacidade contributiva do indivíduo para que exista a imposição do tributo, que deve ser instituído sem violar

SILVEIRA, Rodrigo Maito da. Tributação e concorrência. São Paulo: Quartier Latin, 2011, v. IV, p. 69.

8 SILVEIRA, Rodrigo Maito da. Ibidem, p. 69. 
a igualdade. Para ele, portanto, a capacidade contributiva é critério para ser imposta a tributação a determinado sujeito (GRECO apud SILVEIRA, 2011).

A conceituação do princípio da capacidade contributiva considera que a tributação deve incidir dentro da proporção da capacidade econômica do contribuinte, o que traduz a ideia do princípio suum cuique tribuere (dar a cada um o que the pertence). A razão por trás da capacidade contributiva é, além de garantir a eficácia da lei de incidência do imposto, preservar o contribuinte, de tal forma que ele não seja prejudicado por conta de uma tributação excessiva que não observa a igualdade material e acaba prejudicando os meios de subsistência desse contribuinte, o livre exercício de sua profissão e até outros direitos fundamentais, como a igualdade. Observando essa conceituação do princípio, podemos concluir que a igualdade absorve a capacidade contributiva, ou seja, esta seria um desdobramento daquela e não uma regra autônoma. Dentro do campo vasto que é o estudo da igualdade, a capacidade contributiva pode ser vista como uma espécie do gênero igualdade e, por isso mesmo, não pode ser estudada de forma isolada.

Existem diversos outros princípios que balizam uma tributação justa, como a segurança jurídica e os princípios decorrentes da Ordem Econômica, porém destacaremos como objeto de estudo o princípio da neutralidade tributária, o qual se apresenta como um desdobramento do princípio da igualdade (e um subprincípio da capacidade contributiva); um instrumento que visa promover um ambiente equilibrado de concorrência no mercado, ou seja, propõe-se a fomentar a proteção da livre concorrência como um princípio importante da Ordem Econômica, evitando que ocorram distorções causadas pela tributação, seja por conta de razões fiscais ou extrafiscais. No âmbito do estudo da neutralidade, a livre concorrência e a tributação justa estão em constante interseção, pois no momento em que a tributação ameaça violar a capacidade contributiva de um agente econômico, também estará sendo ameaçada sua chance de concorrência igualitária no mercado. A neutralidade, portanto, vem ser aquele princípio que fará com que a tributação justa e a livre concorrência encontrem-se de forma harmoniosa para que não existam impactos negativos.

\subsection{A conceituação do princípio da neutralidade tributária}

Afinal de contas, como podemos entender a neutralidade tributária? Num primeiro momento, estaria ligada à ideia de um sistema tributário ideal e de uma

TORRES, Ricardo Lobo apud AMARO, Luciano. Op. cit., p. 163. 
-• Tributação, direitos fundamentais e desenvolvimento

imposição na qual tributos não devem influenciar comportamentos a ponto de se tornar fundamental para a decisão do agente econômico em suas escolhas no mercado. Fernando Facury Scaff defende a seguinte ideia:

Um dos requisitos para o exercício da livre concorrência, que, como vimos, tem por base primordial o Princípio da Isonomia, é que os tributos sejam economicamente neutros, para que não venham a distorcer os preços praticados pelas empresas dentro de um mesmo mercado relevante. Trata-se do Princípio da Neutralidade Econômica dos Tributos, que impede que este tipo de intervenção econômica do Estado cause desequilíbrios concorrenciais. (SCAFF apud BRAZUNA, 2009, p. 98-99).

No entanto, a tributação puramente neutra é uma utopia, pois o ato de tributar repercute economicamente no mercado e influencia de alguma forma as açôes dos contribuintes, seja em menor ou em maior grau. Isso porque os valores que os agentes pagam em tributos influenciam na equação dos lucros e das despesas de uma operação econômica. Também não podemos esquecer que a tributação não serve somente para arrecadar receitas para o Estado, mas também pode ter efeitos indutores - estimular ou desestimular condutas dos contribuintes -, o que naturalmente faz com que o tributo interfira na economia. Ou seja, independente de qual seja a finalidade que o tributo possui, fiscal ou extrafiscal, não há como defender a ideia de tributos que sejam cem por cento neutros, que não possuam impacto econômico ou influência nas condutas dos contribuintes. Se partirmos da ideia de que a neutralidade é a total ausência de interferência dos tributos no funcionamento livre do mercado, veremos que na sistemática da Constituição Federal, não há de fato neutralidade tributária.

A neutralidade tributária assemelha-se ao princípio da igualdade, apresentando-se como verdadeiro subprincípio deste, uma vez que exige do Estado um tratamento isonômico para com os indivíduos que tutela. Entretanto, a conceituação da neutralidade tributária exige um elemento diferenciador, sob pena de se estar equalizando os significados entre igualdade e neutralidade. $\mathrm{O}$ elemento diferenciador escolhido pelos doutrinadores foi a livre concorrência, o que nos permite migrar de uma visão generalista de igualdade para entendermos uma igualdade mais restrita, que é a neutralidade tributária. Humberto Ávila assim entende:

A neutralidade melhor representa uma manifestação estipulada da própria igualdade na sua conexão com o princípio da liberdade de concorrência, notadamente no aspecto negativo da atuação estatal. (Apud ROCHA e FARO, 2010, p. 25).

Desta forma, a neutralidade tributária poderia ser entendida como uma neutralidade na atuação do Estado, quando exerce seu poder de tributar, na concorrência. 
Esse dever do Estado em sua atuação poderia ser resumido como uma neutralidade tributária concorrencial ${ }^{10}$.

Tal princípio possui dois aspectos, um positivo e um negativo. No aspecto negativo, a neutralidade tem o condão de impedir a utilização das normas tributárias como indutoras sem justificativa para tal. Isso significa que as normas tributárias indutoras precisam possuir um motivo de existirem, seja estimular o consumo de um determinado produto, seja desestimular a adoção de uma conduta que o Estado não quer que seja adotada. Normas indutoras que sejam instituídas com uma justificativa passam a ter caráter extrafiscal, ou seja, não há nesse caso violação à neutralidade tributária e nem à livre concorrência, porque uma discriminação justificada não viola a igualdade. Do lado do aspecto positivo, temos a ideia de que os tributos podem ser usados para equalizar os distúrbios concorrenciais, o que também deve ser feito de maneira fundamentada, já que será através da adoção de critérios especiais de tributação - uma forma diferenciada de tributar, conforme estudaremos no capítulo seguinte. Vale ressaltar que esse reequilíbrio não pode ser feito através da coibição de condutas abusivas dos agentes que se encontram atuantes no mercado econômico, pois pode acarretar a subversão de uma característica do tributo, qual seja, não ser uma sanção por ato ilícito. Não se deve usar a tributação como forma de punição, mas sim como um meio de promoção de equilíbrio, restaurando o status quo ante.

Com esses conceitos em mente, o Estado pode atuar de duas formas:

1. Tentando reconstruir a igualdade, o que acarreta na necessidade de o Estado atuar corrigindo os desequilíbrios causados pela tributação a contribuintes descritivamente iguais, de modo que a situação de igualdade retorne e seja protegida a livre concorrência. Nessa forma de atuação do Estado, a neutralidade tributária irá vincular a ideia de que a tributação terá como finalidade o reestabelecimento das condições concorrenciais que sejam ideias para o normal funcionamento do mercado.

2. Tentando manter a igualdade, ou seja, manter a situação em que os contribuintes estavam descritivamente desiguais, mas que depois, através da

10 FERRAZ JÚNIOR apud LIMA, Ricardo Seibel de Freitas. Livre concorrência e o dever de neutralidade tributária. Porto Alegre, Universidade Federal do Rio Grande do Sul, 2005. Tese (Mestrado) - Programa de Pós Graduação da Universidade Federal do Rio Grande do Sul, 2009, p. 61. 
•• Tributação, direitos fundamentais e desenvolvimento

tributação, ficaram em situação de isonomia. Neste aspecto da atuação estatal, a neutralidade tributária pode ser entendida como a não interferência de maneira aleatória do Estado no mercado através da tributação. Por "maneira aleatória”, estamos nos referindo às normas tributárias indutoras que não possuam uma finalidade delimitada. A tributação não deve ser criadora de privilégios concorrenciais não justificados entre os agentes que atuam no mercado, sob pena de violar a neutralidade.

Podemos utilizar a conclusão de Ricardo Seibel Freitas Lima para resumir essa atuação estatal:

A neutralidade tributária, desse modo, pode ser entendida, em primeiro plano, como um dever negativo, ou de omissão ao Estado, de não interferir na concorrência por meio da tributação, e, em segundo plano, como um dever positivo ou de ação, de prevenir ou restaurar, quando for o caso, a igualdade de condiçóes na concorrência, quando esta se encontre ameaçada por ações de particulares ou outros fatores relevantes, sempre objetivando a preservação da igualdade de condições competitivas no mercado. (Apud Brazuna, 2009, p. 100).

Ainda sobre essa dupla atuação que o Estado pode promover, Fritz Neumark conclui:

La consecuencia que puede deducirse de todo ello es doble: por uma parte, de carácter negativo: la política fiscal no debiera intervenir en el mecanismo competitivo allí donde exista uma competencia (aproximadamente) perfecta y donde sus resultados no se contrapognan a los postulados político-económicos y político-sociales considerados como de rango superior (incluidos los principios de justicia); por otra parte, de carácter postivo (sic): parece procedente realizar una política fiscal que estimule la competencia en tanto ésta sea imperfecta por razones no fiscales y, por consiguinte, se produzcan consecuencias que, desde el punto de vista económico y/o ético-social hayan de considerarse como prejudiciales. (Apud Luiz Fernando Barboza dos Santos, 2013, p. 6-7).

Quando ocorre a promoção da neutralidade, além de defender a livre concorrência entre os agentes econômicos atuantes no mercado, também acarreta na promoção do princípio da isonomia, uma vez que está implícita na ideia de livre concorrência a igual oportunidade aos agentes econômicos. Anteriormente, traçamos as diferenças entre a neutralidade, a igualdade e a livre concorrência, bem como os pontos de convergência, mas no momento em que a neutralidade é promovida, naturalmente a igualdade e a livre concorrência também estarão protegidas. São conceitos diferentes, porém atuam em conjunto.

Para que a neutralidade tributária seja promovida, assim como a igualdade, é importante que sejam utilizados como instrumentos os critérios especiais de 
tributação que o artigo 146-A da Constituição Federal alude e que irão induzir os agentes a tomarem atitudes que sejam capazes de restabelecer o equilíbrio na concorrência nos casos em que o abalo sofrido nas relações concorrenciais ocorreu por causa da tributação. Esses critérios estão relacionados à estrutura da norma tributária e almejam modificá-la de forma que promova o reequilíbrio concorrencial num mercado que teve sua concorrência maculada por uma tributação irregular ou excessiva.

\subsubsection{Relação da neutralidade tributária com os Impostos Indiretos}

Ao falarmos de neutralidade tributária, é importante estabelecermos a relação entre o princípio e os impostos indiretos, quais sejam, ICMS (Imposto de Circulação de Mercadoria e Serviços) e o IPI (Imposto sobre Produtos Industrializados).

Uma das características desses impostos é o princípio da não cumulatividade, o que implica dizer que eles devem ser neutros no sentido amplo e não podem ferir as leis da livre concorrência. Dizer que devem ser neutros em sentido amplo significa reconhecer que, em caráter fiscal, devem obedecer à neutralidade, mas que perderão essa característica quando forem utilizados de forma extrafiscal, ou seja, quando pretenderem influenciar no mercado econômico as condutas dos agentes.

O princípio da não cumulatividade pode ser entendido como uma onerosidade que incide somente no valor agregado de cada fase da circulação jurídica da mercadoria, o que faz com que exista a mesma formação de preço e de competitividade entre os agentes independentemente do tamanho do circuito jurídico e da quantidade de operaçõos realizadas. Em outras palavras, esse princípio aplica-se aos casos em que existe uma tributação numa cadeia produtiva e visa evitar uma "tributação em cascata", fazendo com que o contribuinte seguinte da operação possa abater o tributo pago anteriormente e pagar o restante que falta, uma vez que irá incidir somente no valor em que for agregado nessa fase da operação. Desta forma, as empresas irão se encontrar em situação de igualdade e consequentemente em equilíbrio concorrencial, pois o pagamento de tributo será proporcional ao valor agregado.

Tendo isso em mente, temos que observar que esses impostos devem tributar as operações de forma neutra, de tal forma que não existam privilégios para mercadorias ou serviços, sejam eles provenientes do próprio país ou de país estrangeiro. O mesmo deve ser observado nas operaçōes ocorridas de um estado para outro, uma vez que favorecimentos tributários entre estados-membros fomentam uma 
•• Tributação, direitos fundamentais e desenvolvimento

guerra fiscal que viola princípios constitucionais básicos para o funcionamento da Federação. A base de cálculo dos impostos de indiretos também deve estar em conformidade com o princípio da neutralidade tributária, devendo ser coerente com os preços usualmente praticados no mercado econômico para que não ocorra uma distorção na concorrência por conta de uma tributação desproporcional. $\mathrm{O}$ uso de uma base de cálculo que não está pautada nos preços usualmente praticados irá gerar um montante errado de tributo a se pagar, o que acaba por prejudicar o contribuinte e macula a livre concorrência, bem como a neutralidade tributária.

\subsection{Da tributação e o desequilíbrio concorrencial}

Para que seja mais palpável a visualização de como a tributação pode ser influente na livre concorrência, vamos utilizar os exemplos dados por Ricardo Seibel de Freitas Lima em sua tese de mestrado sobre a neutralidade tributária e a concorrência ${ }^{11}$.

\subsubsection{Concessões de incentivos e benefícios fiscais}

A concessão de incentivos e benefícios fiscais é um tema que pode vir associado a uma gama de outras questôes, como a guerra fiscal, disputas entre estados-membros com o intuito de atrair investimentos em seu território ou até para debater a renúncia de receita tributária. No entanto, vamos abordar sua relação com a livre concorrência, tendo em vista que já debatemos nesse trabalho que a neutralidade tributária está associada à tributação que causa distúrbios na concorrência. Não poderia ser diferente o debate, é necessário observar de que forma esse distúrbio ocorre para podermos entender a importância do artigo 146-A, CRFB/88.

O benefício fiscal está vinculado à concepção de uma redução ou até eliminação do ônus tributário por meio de lei infraconstitucional. Quando um incentivo ou benefício fiscal é concedido, ele acaba desonerando um contribuinte que está presente numa relação jurídico-obrigacional tributária. Da mesma forma, ao desonerar um contribuinte, o incentivo ou o benefício fiscal onera o outro sujeito da relação. Conclui-se então, que ao fazer isso, essa lei que concede ou o incentivo ou

LIMA, Ricardo Seibel de Freitas. Livre concorrência e o dever de neutralidade tributária. Porto Alegre, Universidade Federal do Rio Grande do Sul, 2005. Tese (Mestrado em Direito) - Programa de Pós Graduação em Direito da Universidade Federal do Rio Grande do Sul, Porto Alegre, 2005. 
o benefício fiscal influencia no andamento normal da concorrência, já que um dos contribuintes irá pagar menos ou nenhum tributo enquanto o outro pagará normalmente o valor que lhe é cabível. Benefícios fiscais e incentivos podem abranger: subsídios e benefícios fiscais, incentivos fiscais, subsídios de natureza financeira, tributária e creditícia, isenções, remissões, anistia, concessão de crédito presumido, redução na base de cálculo ou nas alíquotas etc.

Ricardo Seibel de Freitas Lima exemplifica a relação dos benefícios e incentivos fiscais e a livre concorrência através de um caso ocorrido no Rio Grande do Sul em que uma montadora de automóveis recebeu concessóes fiscais para fixar suas bases no território do estado ${ }^{12}$. Por causa dessas concessões, o Pensamento Nacional das Bases Empresariais consultou o CADE (Conselho Administrativo de Defesa Econômica), que entendeu que a concessão desses benefícios e incentivos fiscais pode ser muito prejudicial à livre concorrência e, consequentemente, à igualdade e à neutralidade tributária. Entende-se dessa forma porque, ao ser concedido tal benefício à empresa, ocorre um desnivelamento no campo de atuação econômica, o que prejudica as iguais condiçôes de mercado e, assim, acaba por afetar também o funcionamento da concorrência entre os agentes. Através desses favorecimentos concedidos, o agente beneficiado poderá instituir um valor muito mais baixo ao seu produto, uma vez que efetua poucos gastos com tributação ou até não efetua gastos e não precisará repassar esse valor ao produto final, ou até aproveitar para aumentar sua lucratividade, o que por si só já permite que a empresa se posicione numa situação mais vantajosa que as outras empresas. Ponderar acerca desses incentivos fiscais não é o mesmo que tirar sua legitimação constitucional de existência, mas sim perceber que a maioria desses benefícios é concedida à revelia da lei. Isso ocorre na maioria das vezes com o ICMS, tendo em vista o cenário de guerra fiscal existente entre os estados-membros. Portanto, é possível conceder benefícios fiscais de forma legítima, com fundamento em permissivo constitucional, mas desde que obedeça a princípios como a legalidade e encontrem-se adequados para o fim a que se propõem. Somente perde a legitimidade aquele incentivo fiscal que não está fundamentado com uma finalidade e viola os princípios tributários.

De qualquer forma, legítima ou não, a concessão de benefícios fiscais causa um impacto na concorrência, já que, conforme estudamos nesse capítulo, não é

12 LIMA, Ricardo Seibel de Freitas. Op. cit. 
•• Tributação, direitos fundamentais e desenvolvimento

possível sustentar a ideia de que a tributação é puramente neutra. Se o benefício for concedido de forma ilegítima, ou seja, violando princípios tributários e sem qualquer justificativa, deverá ser suspenso por contrariar o direito através do controle de constitucionalidade. Nesse momento, o artigo 146-A, CRFB/88 poderá desempenhar um papel importante, de forma que coíba guerra fiscal entre os entes públicos por conta de uma tributação - no caso, um benefício fiscal - que causou um desequilíbrio na concorrência. Por meio de um critério especial de tributação, essa norma tributária terá a função de reduzir ou afastar os efeitos que a primeira norma tributária causou. Se for legítimo e ainda assim causar um desequilíbrio na concorrência, a premissa será de que esse benefício será justificado, pois almeja alcançar um objetivo proposto que não seria alcançado se não fosse essa indução de comportamento.

\subsubsection{Imunidade tributária e exercício de atividade econômica}

A Constituição Federal, no momento em que define a competência tributária dos entes da Federação, institui a cada uma dessas pessoas o poder de tributar contribuintes que se encaixem na hipótese de incidência do tributo e pratiquem o fato gerador. Todavia, a própria Constituição apresenta situações que não podem ser oneradas pela tributação, excluindo-as do poder de tributar dos entes, com a justificativa de se almejar fins públicos. A imunidade pode ser concedida a objetos, pessoas, serviços, situações ou bens. $\mathrm{O}$ grande ponto de diferença entre isenções e imunidades é que esta é concedida pela Constituição Federal e aquela, por meio de lei infraconstitucional.

Os primeiros sinais de problema ocorrem quando as pessoas contempladas pela imunidade começam a ingressar no mercado exercendo atividades econômicas, de forma que a relação entre elas e os outros agentes que não possuem imunidade fica prejudicada. Não existe igualdade entre os agentes, pois um realiza gastos com tributos - que irão influenciar no fluxo de lucros e despesas da empresa - enquanto o outro não realiza quaisquer gastos por estar fora do campo de incidência do tributo. Dessa forma, o valor dos produtos ofertados por esses agentes será diferente por causa da desigualdade da aplicação da norma tributária. Nesse caso, será necessário realizar uma ponderação entre os princípios envolvidos: o princípio do interesse público da concessão da imunidade e o interesse particular que foi restringido pela concorrência. 


\subsubsection{Tratamento tributário diferenciado para as importações}

Por fim, mas sem possibilidade de esgotar o tema, podemos citar a tributação que concede tratamentos privilegiados às importaçôes, o que visivelmente prejudica a igualdade entre os agentes e, consequentemente, viola a livre concorrência. Quando se trata de um tributo como o ICMS, a tributação deve obedecer à neutralidade tributária, uma vez que se trata de um imposto indireto e, pautado nisso, deve dispensar o mesmo tratamento às operações ou prestações de serviço, independente se iniciaram fora do país ou dentro. Acerca disso, num primeiro momento o STF entendeu que não haveria a incidência do ICMS sobre os bens importados por pessoas físicas que não repassarão esse bem adiante, uma vez que não haveria compensação no pagamento do tributo nas operações seguintes, pois elas não existirão. Ricardo Seibel entende que essa posição do STF é equivocada, já que a incidência do ICMS independente de operação iniciada no exterior ou dentro do território nacional brasileiro ${ }^{13}$.

Quando a operação é iniciada no território interno, o sujeito passivo desse tributo será aquele que faz a mercadoria circular, apesar de os ônus econômicos recaírem sobre o agente que se encontra no final da cadeia de operações econômicas. Já quando a operação é iniciada no exterior, a sujeição passiva é de quem recebe o bem, independentemente de ser pessoa física ou jurídica. Por conta da não cumulatividade, não havendo incidência anterior na cadeia de operações, não há que se falar em ICMS a ser suportado pela pessoa física. Esse antigo entendimento importava na quebra do princípio da neutralidade tributária, já que os contribuintes não se apresentavam de forma igualitária no mercado econômico.

Qual foi a solução encontrada para o problema? Inicialmente, os importadores defendiam a posição de que a cobrança do tributo ocorreria somente após a entrada da mercadoria no estabelecimento, o que os eximia do pagamento do tributo. Esse entendimento foi o mesmo do STF por anos, sendo inclusive sumulado na Súmula n. 577. Na vigência da Constituição de 1988, o debate foi reaberto e o entendimento da súmula foi modificado. Com isso, foi editada a Emenda Constitucional em 2001 para modificar o artigo 155, IX, “a”, que deixou expresso que haverá a incidência de ICMS no caso de importação de mercadoria por pessoa física ou jurídica, sendo este o contribuinte, mesmo que não seja o usual. Dessa

13 LIMA, Ricardo Seibel de Freitas. Op. cit. 
•• Tributação, direitos fundamentais e desenvolvimento

maneira, foi assegurada a defesa da neutralidade tributária e da livre concorrência no que tange a tributação sobre operações iniciadas no exterior ou no mercado interno, garantindo que assim não haverá privilégio para mercadorias importadas.

Conclui-se, portanto, que é importante que as tributações sobre importações não atentem contra a neutralidade tributária, sob risco de desequilibrar o funcionamento da livre concorrência e por consequência também violar a igualdade de condições entre os agentes econômicos. Aliás, é importante que a tributação no geral não atente contra a neutralidade tributária. A seguir iremos abordar a estrutura do artigo 146-A, CRFB/88, de forma que possamos entender sua importância para nossa discussão acerca da defesa da neutralidade tributária e, assim, também da livre concorrência.

\section{A EMENDA CONSTITUCIONAL 42 DE 2003 E A INTRODUÇÃO DO ARTIGO 146-A}

A Proposta de Emenda Constitucional 41 foi apresentada em 30 de Abril de 2003 e a Emenda Constitucional n. 42 publicada em 19/12/2003. Sua proposta foi uma tentativa de efetivar uma reforma tributária, com a intenção de "elevação de sua a eficiência econômica brasileira, estimular a produção, o investimento produtivo e a geração de emprego e renda" ${ }^{14}$. Dentre as justificativas apresentadas, estava a de reorganizar o Sistema Tributário Nacional para promover um bom funcionamento da economia.

No que tange as normas que foram reformadas ou acrescidas por meio dessa Emenda Constitucional, o artigo 146-A, objeto de estudo desta monografia, voltou-se à prevenção dos desequilíbrios concorrenciais por meio de critérios especiais de tributação. $\mathrm{O}$ artigo, em ipsis literis:

Art. 146-A. Lei complementar poderá estabelecer critérios especiais de tributação, com o objetivo de prevenir desequilíbrios da concorrência, sem prejuízo da competência de a União, por lei, estabelecer normas de igual objetivo. (Incluído pela Emenda Constitucional n. 42, de 19.12.2003).

Para melhor estudarmos o artigo proposto, é necessário seu desmembramento, uma vez que se trata de uma norma complexa e com diversos subitens a serem conceituados e discutidos.

14 BRASIL. Proposta de Emenda Constitucional 41 de 2003. Brasília: Distrito Federal. Disponível em: <http://www.camara.gov.br/proposicoesWeb/prop_mostrarintegra?codteor=129816\&fil ename $=\mathrm{PEC}+41 / 2003>$. Acesso em: 18 maio 2015 . 


\subsection{A Lei Complementar com condão de prevenir desequilíbrios concorrenciais}

\subsubsection{A Lei Complementar}

O primeiro aspecto a ser observado no art. 146-A é que ele se destina ao legislador complementar e que apresenta uma atribuição adicional ao rol de competências já existentes da lei complementar em matéria tributária, presentes no art. 146, $\mathrm{CRFB} / 88$. O instrumento escolhido pelo constituinte derivado para chegar à finalidade pretendida pelo artigo 146-A foi, portanto, a lei complementar. Essa espécie de lei, além de regular o poder de tributar, de estabelecer regras gerais de tributação e de dispor sobre os conflitos de competência entre os entes da Federação, também deverá regulamentar os critérios especiais de tributação com o condão de prevenir os desequilíbrios concorrenciais. Pode-se entender o art. 146-A tanto como uma norma de competência que autoriza a adoção de critérios especiais de tributação para remediar uma determinada situação quanto uma norma que consagra um princípio: o da neutralidade tributária.

É uma norma que se direciona ao legislador complementar, prescrevendo a necessidade da criação de uma lei complementar. Nesse artigo, o próprio legislador infraconstitucional estabelecerá a norma com os critérios especiais de tributação, diferentemente de diversos artigos de competência presentes na Constituição, nos quais os critérios especiais de tributação poderão ser definidos por outros instrumentos legislativos. Em termos simplificados: o próprio legislador complementar irá estabelecer tais critérios especiais de tributação, e não outros legisladores. Cabe mencionar que na visão de Luís Eduardo Schoueri essa norma não se trataria de uma norma criadora de tributos, mas sim uma forma diferenciada no ato de tributar, uma mudança nos critérios que compõem a norma de incidência tributária ${ }^{15}$.

\subsubsection{A competência legislativa}

A segunda questão a ser tratada é: quem possuiria a competência para editar essa lei complementar? Os Estados, Distrito Federal e Municípios ou a União? Tendo em vista que a Constituição Federal estimula que as normas e os atos da Administração Pública sejam criados visando o desenvolvimento nacional, a conclusão que podemos obter é que a melhor escolha seria por uma lei complementar

15 SCHOUERI apud BRAZUNA. Op. cit., p. 90. 
-• Tributação, direitos fundamentais e desenvolvimento

do legislador nacional. Desta forma, os critérios especiais de tributação seriam destinados a todos os entes e o combate aos desequilíbrios de concorrência seria feito de maneira uniforme. Acerca disso, Vinícius Alberto Rossi Nogueira, em sua tese de mestrado, constata:

Outro ponto relevante é que a Constituição, por meio do artigo 24, I, atribuiu competência aos Estados e aos Municípios para legislar sobre direito econômico. Adiante, nos artigos 155 e 156, ficaram estabelecidas as respectivas competências tributárias para os entes federativos. Portanto, da conjunção do artigo 24 com o artigo 155 ou 156, Estados e Municípios já estariam autorizados a desenvolver normas tributárias indutoras para promover a concorrência em seus respectivos territórios, não havendo necessidade da edição do artigo 146-A para tanto. ${ }^{16}$

No entanto, o artigo também menciona a possibilidade de a União remediar desequilíbrios na concorrência por meio de lei ordinária no seguinte trecho: “(...) sem prejuízo da competência de a União, por lei, estabelecer normas de igual objetivo.”. Essa regulação que o artigo alude é feita por força do artigo 173, $₫ 4^{\circ}$, CRFB/88, que dispõe:

Art. 173. Ressalvados os casos previstos nesta Constituição, a exploração direta de atividade econômica pelo Estado só será permitida quando necessária aos imperativos da segurança nacional ou a relevante interesse coletivo, conforme definidos em lei.

(...)

$\$ 4^{\circ}$ lei reprimirá o abuso do poder econômico que vise à dominação dos mercados, à eliminação da concorrência e ao aumento arbitrário dos lucros.

Os dois textos constitucionais, quando interpretados em conjunto, levam-nos à conclusão de que a União também pode legislar por meio de lei ordinária buscando assegurar o exercício da livre concorrência. Contudo, se a União pode editar essa norma com critérios especiais de tributação por meio de lei ordinária, que tem um processo legislativo muito mais simplificado e quórum menos qualificado, por que o faria por meio de lei complementar? É importante entender que essa norma encontra limites na própria competência da União, que se restringem à administração do tributo que recolhe, quais sejam os tributos de âmbito federal. Como conclusão, Vinícius Alberto Rossi Nogueira entende que as competências da União e do legislador complementar, no que tange o artigo 146-A, não entram em conflito, mas sim coexistem, sem prejuízo uma da outra, mesmo que elas possuam o mesmo objetivo. Não existiria, portanto, conflito entre as competências, pois uma trata da intervenção no domínio econômico e a outra, normas tributárias com efeito fiscal sobre a livre

NOGUEIRA, Vinícius Alberto Rossi. Op. cit., p. 66. 
concorrência. Para ele, o artigo estaria se direcionando apenas aos Estados, Distrito Federal e Municípios, já que a União legislaria por meio da lei ordinária ${ }^{17}$.

Esse posicionamento não é compartilhado por José Luis Ribeiro Brazuna, Diego Bonfim e José Afonso da Silva. Os ilustres autores entendem que a competência da União presente no artigo 146-A, CRFB/88, exclui a competência do artigo $173, \$ 4^{\circ}$, que é voltada para a legislação sobre abuso de poder econômico no mercado. Desta forma, entendem que os artigos 146-A e 173, $\$ 4^{\circ}$ tratam de questôes diferentes, o que faz com que a União esteja inserida na criação dessa lei complementar que irá estabelecer critérios especiais de tributação. Com base nisso, não há qualquer conflito de competência, pois a regulamentação do abuso de poder econômico seria feita por meio de Lei Ordinária e o reestabelecimento do equilíbrio da livre concorrência, por meio de lei complementar ${ }^{18}$.

Em resumo, existem dois posicionamentos acerca da competência da União:

1. Acredita que a União não está inserida no campo de incidência do artigo 146-A por conta da existência do artigo $173, \S 4^{\circ}$, que já garantiria que a União pudesse regular, por meio de lei ordinária, os desequilíbrios concorrenciais. Embora uma seja norma tributária e a outra concorrencial, ambas possuem o mesmo objetivo, por isso a competência aludida no artigo 146A está direcionada aos outros entes: Estados, Distrito Federal e Municípios.

2. Acredita que a União está inserida no campo de incidência do artigo 146-A, pois a competência desse referido artigo não se relaciona com competência existente no artigo $173, \mathbb{S} 4^{\circ}$, uma vez que são normas de conteúdos diferentes. $\mathrm{O}$ estabelecimento de critérios especiais de tributação para prevenir desequilíbrios concorrenciais é uma norma tributária e deve ser feita, conforme preceitua o artigo 146-A, por meio de lei complementar. Já a regulação do abuso de poder é matéria que deve ser tratada por meio de lei ordinária, através da União.

\subsubsection{Critérios especiais de tributação}

A terceira questão que precisamos abordar é sobre os critérios especiais de tributação. Para entendermos de que forma irão funcionar os critérios especiais,

17 NOGUEIRA, Vinícius Alberto Rossi. Ibidem.

18 Ibidem. 
•• Tributação, direitos fundamentais e desenvolvimento

precisamos entender como funciona a estrutura da norma tributária e, para isso, estudaremos a regra matriz de incidência dos tributos. Utiliza-se a regra matriz de incidência como técnica para compreendermos como funciona o fenômeno jurídico-tributário que dá origem à relação jurídica entre o particular e o Estado. É nessa relação jurídico-tributária que surgem as obrigaçōes principal e acessória que devem ser cumpridas pelo contribuinte definido pela norma. Divide-se o estudo da regra matriz de incidência da norma tributária em antecedente e consequente normativo.

$\mathrm{O}$ antecedente normativo é composto por três critérios: material, temporal e espacial. O primeiro que iremos analisar é o critério material, no qual temos o fato gerador. Caracteriza-se como a descrição do fato ou conjunto de fatos que ensejarão a tributação, ou seja, aquela situação que legalmente gerará a obrigação tributária. O fato gerador está definido no artigo 114 do Código Tributário Nacional (CTN): "Fato gerador da obrigação principal é a situação definida em lei como necessária e suficiente à sua ocorrência. (Grifo nosso)." ${ }^{\prime \prime}$, usando o termo para referir-se tanto à hipótese de incidência (a circunstância abstrata que é definida pelo legislador na norma tributária) quanto ao fato imponível (o fato em concreto, chamado de "fato jurídico tributário" por Paulo de Barros Carvalho ${ }^{20}$ ). Diante dessa ressalva, o termo mais correto para referir-se ao critério material da regra matriz de incidência será "hipótese de incidência", que não depende do elemento volitivo para se configurar, ou seja, independe da vontade das partes. Por meio do critério material, iremos identificar qual o tributo para aquela situação e sua competência tributária.

O segundo critério do antecedente normativo, o temporal, caracteriza-se como o momento a partir do qual se considerará constituída a obrigação tributária, que será definido pela lei que instituir o tributo em questão. Acerca disso, cabe salientar que existem hipóteses tributárias instantâneas e periódicas, que irão modificar esse momento de constituição da obrigação tributária. As hipóteses tributárias instantâneas são aquelas que se esgotam num certo, determinado período de tempo, enquanto as periódicas caracterizam-se pelo fato gerador (a hipótese de incidência) que se estende no tempo, não havendo um momento certo de sua ocorrência. O terceiro, e último, critério do antecedente normativo é o espacial, que se vincula ao território em que aquele tributo incide.

19 BRASIL. Código Tributário Nacional (1966). Brasília, Distrito Federal: Senado Federal, 1966. Art. 114.

20 CARVAlHO, Paulo de Barros. Curso de direito tributário. 26. ed. São Paulo: Saraiva, 2014. 
Do outro lado, temos o consequente normativo da regra matriz de incidência, que se refere ao momento após a prática do fato gerador, quando se instaura a relação jurídico-tributária. É nesse momento, então, que nasce a obrigação tributária, a qual tem por objeto o pagamento do tributo. A obrigação tributária está presente no artigo 113 do CTN:

Art. 113. A obrigação tributária é principal ou acessória.

$\$ 1^{\circ}$ A obrigação principal surge com a ocorrência do fato gerador, tem por objeto o pagamento de tributo ou penalidade pecuniária e extingue-se juntamente com o crédito dela decorrente.

$\$ 2^{\circ}$ A obrigação acessória decorre da legislação tributária e tem por objeto as prestaçóes, positivas ou negativas, nela previstas no interesse da arrecadação ou da fiscalização dos tributos.

$\$ 3^{\circ}$ A obrigação acessória, pelo simples fato da sua inobservância, converte-se em obrigação principal relativamente à penalidade pecuniária. (Grifos nossos). ${ }^{21}$

Os critérios presentes no consequente normativo da regra matriz de incidência são o quantitativo e o pessoal. O critério quantitativo é relativo ao cálculo do tributo objeto da obrigação, ou seja, o valor que deverá ser pago a título de tributo. Nesse critério, temos dois outros elementos: a base de cálculo e a alíquota. A base de cálculo possui uma relação íntima com o aspecto material da hipótese de incidência, não podendo ser escolhida de forma ilimitada, mas dentre as bases de cálculo previstas pela $\mathrm{CRFB/88}$. Existe a base de cálculo postnumerando, que é aquela apurada somente após a ocorrência do fato jurídico-tributário, como é o caso do ICMS, onde se precisa conhecer primeiro o valor da operação tributada para depois se atribuir uma base de cálculo. Também existe a base de cálculo praenumerando, que se vale de uma grandeza presumida, como ocorre no PIS, em que se considera como base de cálculo o faturamento do sexto mês anterior ao fato gerador. Existem outros critérios que podem contribuir para a formação da base de cálculo, como caso da capacidade contributiva, os métodos indiretos de apuração (lucro presumido e margens predeterminadas dos preços de transferência). Já a alíquota é, via de regra, um percentual cobrado em cima da base de cálculo, podendo até ser fixa nos casos em que a base de cálculo não é expressa em valor, mas sim por outro tipo de quantificação.

O último critério do consequente normativo da regra matriz de incidência é o pessoal, que versa sobre os sujeitos que estarão presentes nessa relação jurídico-

$21 \quad$ BRASIL, Ibidem. Art. 113. 
•• Tributação, direitos fundamentais e desenvolvimento

-tributária. Temos de um lado o sujeito ativo, aquele que é o titular da capacidade tributária ativa, sendo, em regra, a mesma pessoa jurídica de direito público que tem a competência para instituir o tributo. Do outro lado, o sujeito passivo caracteriza-se como o indivíduo obrigado ao pagamento do tributo, podendo ser o contribuinte ou uma terceira pessoal que será definida como responsável tributário. A definição de quem é o contribuinte de um determinado tributo será realizada através do estudo do critério material, ou seja, da hipótese de incidência. Aquele que pratica o fato gerador será considerado o contribuinte daquele determinado tributo. No entanto, temos a figura do responsável tributário, aquele que pagará o tributo no local do contribuinte, que deverá ser determinado mediante lei.

Depois de entendida a regra matriz de incidência, vamos abordar a extrafiscalidade dos tributos. Os tributos possuem uma finalidade primária, que é obtenção de recursos para que o Estado possa efetuar suas despesas necessárias. Contudo, a tributação já é utilizada há muito tempo para a obtenção de resultados diversos que não só a arrecadação de receita, podendo também se utilizada para resultados econômicos e políticos, quais sejam: reprimir inflação, desemprego, refrear uma determinada atividade econômica etc. Essa classificação entre tributo fiscal e extrafiscal é feita para que possamos identificar tributos nos quais sua finalidade maior é arrecadar receitas e tributos que, embora arrecadem receita, possuem outros objetivos, como o de influenciar o comportamento do contribuinte, seja por meio da sua oneração ou desoneraçãa. A extrafiscalidade do tributo é feita mediante adoção de critérios de discriminação para se alcançar um objetivo estabelecido pelo constituinte, desde que essa discriminação seja pautada no princípio da isonomia, como vimos anteriormente.

Utilizando a estrutura da norma tributária proposta por Luís Eduardo Schoueri ${ }^{22}$, podemos observar que existe uma norma tributária primária, que possui como foco essencial a arrecadação de recursos, e uma norma tributária secundária na qual se visa que um comportamento seja atingido por meio de um tratamento tributário específico, seja através do estímulo ou do desestímulo da conduta. O autor chama esta norma de norma tributária indutora. A norma tributária indutora tem a característica de induzir comportamentos nos contribuintes, mas deve existir um controle nessa indução. Acerca disso, Misabel Abreu Machado Derzi ensina:

SCHOUERI apud BRAZUNA, op. cit., p. 85. 
O art. 146-A da Constituição Federal e o Princípio da Neutralidade Tributária •

Os benefícios, isenções, incentivos regionais ou setoriais somente são admitidos pela Constituição quando existirem razões de justiça social, superior interesse público e sempre para reverter em favor da coletividade como um todo. (Apud SCHOUERI, Luís Eduardo, Normas tributárias indutoras e intervenção econômica, Forense, 2005, p. 290).

Agora vamos ao ponto principal: os critérios especiais de tributação. $\mathrm{O}$ que seriam? $\mathrm{O}$ artigo 146-A não determina quais são esses critérios especiais, mas se pode concluir que seria a possibilidade de incluir novos critérios a uma tributação já existente. Não se trata de novos tributos ou de uma "tributação especial", mas sim de critérios novos, especiais, que estarão presentes dentro da norma tributária, com o fim de corrigir os problemas concorrenciais. Seria, portanto, uma modificação na já existente estrutura da relação tributária, podendo ser qualquer elemento de sua constituição, como quem será o responsável tributário ou como será recolhido esse determinado tributo, dentre outros elementos. Rodrigo Maito da Silveira exemplifica quais seriam essas mudanças:

Os critérios especiais de que trata o artigo 146-A podem, por exemplo, estabelecer determinados parâmetros para (i) a concessão de incentivos fiscais, ou (ii) a utilização de procedimentos voltados à praticabilidade, como substituição tributária, ficções e presunções legais, a responsabilização de terceiros, obrigações acessórias etc. (Apud NOGUEIRA, 2014, p. 76).

José Luís Ribeiro Brazuna entende que esses critérios especiais seriam os mesmos elementos para se instituir a obrigação do pagamento do tributo, quais sejam, os elementos presentes na regra matriz de incidência do tributo, como o antecedente (caráter material, espacial e temporal) e o consequente (critérios pessoal e quantitativo $)^{23}$. Dos elementos da estrutura da norma tributária, poderão ser usados para instituir normas tributárias indutoras as discriminações de situações (critérios material, temporal e especial) ou de sujeitos passivos (pessoa), que, no caso, terão uma tributação especial mediante aumento ou diminuição da base de cálculo e alíquota (critério quantitativo). Dependendo do caso, será escolhido um desses critérios para induzir ou inibir condutas (que são relacionadas aos fatos abrangidos pela norma de incidência tributária) dos contribuintes.

Ainda, segundo Brazuna ${ }^{24}$, para que a norma atinja a sua finalidade indutora, deve existir uma relação entre a hipótese descrita na norma e o ato do sujeito passivo,

23 BRAZUNA, ibidem, p. 92.

24 Ibidem, p. 92. 
e que tal ato, com o agravamento ou desagravamento, possa ser induzido ou inibido pelo resultado tributário. Quanto ao momento e local, serão escolhidas situações especiais para que se exija pagamento maior ou menor do tributo, com o intuito de estimular ou desestimular a prática do fato gerador em certos momentos ou locais. Em relação ao sujeito passivo, poderá o legislador selecionar características comuns para segregar tipos de sujeitos, que terão obrigações tributárias diferenciadas. Quanto ao critério quantitativo, é possível que o legislador manipule alíquotas, mas deverá reservar cuidado em relação à base de cálculo para que esta não seja modificada a ponto de desconfigurar o critério material da norma de incidência tributária.

Schoueri entende que a isenção tributária se encontra numa posição de destaque como técnica de indução de comportamentos no contribuinte e Brazuna, que as isenções poderiam ser utilizadas para fins de aplicação do artigo 146-A, uma vez que modificam aspectos da norma de incidência, o que resulta na redução, seja total ou parcial, do tributo. O autor preceitua que para a finalidade do artigo 146A ser atingida, não deveria haver limitação ao uso das normas tributárias para prevenir distúrbios concorrenciais ${ }^{25}$.

Vinícius Alberto Rossi Nogueira, assim como Ricardo Sibel Freitas de Lima, entende que o artigo é mais amplo, por não fazer menção de que a lei tem que ser de natureza indutora, o que permite que os critérios especiais tenham ou não efeito indutor. $\mathrm{O}$ autor menciona que não há menção no artigo de que essa norma deve ter efeito indutor. Isso nos leva à conclusão de que o artigo 146-A alcança também as obrigações acessórias tributárias, desde que o objetivo seja corrigir problemas concorrenciais. Para ele, não há discussão quanto à possibilidade de uma obrigação acessória produzir um efeito que seja extrafiscal, mas que não seja uma norma indutora ${ }^{26}$. No entanto, José Luís Ribeiro Brazuna entende que o verdadeiro objetivo deste artigo seria o efeito indutor do tributo, o que acarretaria em dizer que ele somente estaria direcionado à obrigação principal do tributo, e não a sua obrigação acessória. Entende dessa forma porque o texto constitucional autorizou que fossem utilizadas normas tributárias indutoras, que só derivam normas de incidência tributária, enquanto as obrigações acessórias seriam utilizadas apenas para fiscalizar e controlar a arrecadação do tributo, não sendo meio adequado de indução de comportamento ${ }^{27}$.

\footnotetext{
Ibidem, p. 93.

26 NOGUEIRA, op. cit., p. 76.

27 BRAZUNA, op. cit., p. 97.
} 


\subsubsection{Prevenção de desequilíbrios concorrenciais}

O último aspecto do artigo a ser analisado é a prevenção de desequilíbrios concorrenciais, que é a finalidade que se deseja atingir ao serem criados os critérios especiais de tributação.

Em prol de um desenvolvimento econômico, a aplicação de legislações que defendam o bom funcionamento da liberdade econômica mostra-se importante. É preciso também impor restrições ao exercício da liberdade de concorrência, de tal forma que seja adequada à alocação de recursos econômicos na atividade produtiva. O que devemos observar com atenção é de que forma devemos agir para que tributação e a concorrência coexistam, de tal maneira que a primeira não tenha impactos negativos na segunda e que ambas possam promover o bem-estar social. Por isso, o que se prega é a "coordenação de políticas públicas de tributação e de defesa da concorrência. ${ }^{28}$ Mas que tipos de desequilíbrios concorrenciais o artigo 146-A pretende prevenir? Seriam aqueles provenientes do próprio funcionamento do mercado ou aqueles que foram provocados pela tributação?

Rodrigo Maito da Silveira, bem como Schoueri, entende que essa norma deve ser voltada apenas para a prevenção de desequilíbrios concorrenciais provenientes da tributação ${ }^{29}$. Através de critérios específicos, o legislador poderá evitar que um tributo tenha efeitos tais que cause desequilíbrios na concorrência, o que leva à conclusão de que tributos não são neutros e que podem sim promover distúrbios na concorrência, uma vez que nem sempre a capacidade contributiva pode ser aplicada aos contribuintes de forma idêntica. É importante frisar que a prevenção desses desequilíbrios concorrências por meio de critérios especiais de tributação deve ser feita de tal forma que não desvirtue a natureza do tributo, ou seja, ele não pode se transformar numa sanção de atos ilícitos.

Quanto às falhas de mercado que causam distúrbios na concorrência, não seria possível que o artigo 146-A atingisse tais situações, já que o legislador, através da tributação, não poderia prever a ocorrência dessas falhas de forma que pudesse fazer uma ação tributária preventiva. $\mathrm{O}$ artigo, como se pode observar, não é amplo o suficiente para ser utilizado também em situaçôes de exercício abusivo da atividade econômica. Não poderia a extrafiscalidade corrigir falhas concorrenciais

28 SILVEIRA, Rodrigo Maito da. Op. cit., p. 35.

29 SILVEIRA, op. cit., p. 103. 
provocadas pelos próprios agentes presentes no mercado. Nesses casos, a norma a ser utilizada para remediar problemas na concorrência causados por condutas abusivas é a Lei n. 8.884/94, que trata do Sistema Brasileiro de Defesa da Concorrência. Brazuna entende que esse artigo se trata de uma intervenção na ordem econômica por meio da indução ${ }^{30}$. A intervenção na ordem econômica pode ser realizada por meio da absorção ou participação - o Estado atua em regime de monopólio ou concorrência com outros agentes privados -, da direção - através da defesa da concorrência, utilizando a prevenção e a repressão do controle das estruturas e dos comportamentos no mercado por parte dos agentes econômicos -, e da indução, que pode ser feita pelo artigo 146- $\mathrm{A}^{31}$. Portanto, as falhas de mercado causadas pelos próprios agentes econômicos é caso para a intervenção por meio da direção, e não da indução, como concluímos anteriormente. Schoueri defende da ideia de que o artigo 146-A somente inovou no sentido de essa norma tributária ser voltada para a prevenção de distúrbios concorrenciais "provocados", já que as normas de ordem estrutural podiam, antes do advento do artigo 146-A, ser objeto de normas tributárias indutoras, como é o caso dos tributos aduaneiros ou da tributação nas operações de aquisição de controle, ou nas fusões e incorporações que gerassem concentração econômica ${ }^{32}$. Da Silveira discorda do pensamento de que o artigo 146-A seja uma forma de intervenção na ordem econômica, entendendo que o referido artigo apenas contempla a possibilidade de o legislador minimizar os efeitos negativos que um tributo pode ocasionar na concorrência, por meio de critérios presentes na lei complementar ${ }^{33}$.

\subsection{Interpretações do artigo 146-A}

Do estudo que fizemos dos elementos que compóem o artigo 146-A, podemos concluir: trata-se de uma norma de competência, que estabelece critérios especiais de tributação e objetiva prevenir distúrbios concorrenciais. José Luís Ribeiro Brazuna propôs em sua tese de doutorado interpretações acerca do artigo e como seria o funcionamento dele na prática, bem como considerações sobre essas interpretações ${ }^{34}$.

\footnotetext{
BRAZUNA, op. cit., p. 90.

31 NOGUEIRA, op. cit., p. 50-55.

32 SCHOUERI apud BRAZUNA, op. cit., p. 94-95.

33 SILVEIRA, op. cit., p. 108.

34 BRAZUNA, op. cit., p. 102-119.
} 
O art. 146-A da Constituição Federal e o Princípio da Neutralidade Tributária ••

- $\quad 1^{a}$ interpretação: O Congresso Nacional seria encarregado de estabelecer os critérios especiais de tributação para todos os tributos. Em se tratando de tributos dos Estados, do Distrito Federal e dos Municípios, o estabelecimento dos critérios especiais seria feito por meio da lei complementar. No caso de tributos da União, por meio da lei ordinária.

- Consideraçóes acerca dessa interpretação: Tal leitura respeitaria a competência da União de poder tratar de concorrência, pois a norma tributária indutora emanaria do Congresso Nacional, seja ela veiculada a tributos dos Estados, Distrito Federal ou Municípios. Roque Antonio Carrazza, no entanto, diz que essa interpretação faria com que se questionasse a constitucionalidade desse artigo, pois "uma emenda constitucional não poderia ter autorizado a União a indicar, ainda que por meio de lei complementar, como as demais pessoas políticas deverão desenvolver a sua tributação." (Apud BRAZUNA, 2009, p. 114-115). Ademais, se tal interpretação fosse utilizada estaria vedado o uso da isenção tributária para os tributos dos Estados, Distrito Federal e Municípios por força do artigo 151, III, CRFB/88.

- $\quad 2^{\mathbf{a}}$ interpretação: A lei complementar editada pelos Estados, Distrito Federal e dos Municípios poderá fixar os critérios especiais de tributação sem qualquer prejuízo da competência da União de estabelecer também critérios especiais de tributação para seus tributos, mas por meio de lei ordinária.

- Considerações acerca da $2^{a}$ interpretação: Essa interpretação não seria compatível com a competência material da União para defender a concorrência. A competência para legislar acerca de Direito Econômico é concorrente, por força dos artigos 24, I e 30, I e II, CRFB/88, mas apesar disso, o tema "concorrência" é de interesse nacional, portanto a competência para defender a concorrência é dominante à União. Apesar de não expresso, o artigo $173, \S 4^{\circ}, \mathrm{CRFB} / 88$, refere-se à lei ordinária da União, por isso exclui outros entes de legislarem sobre o mesmo tema. Os entes precisam obedecer suas competências e cuidar para que suas medidas não desequilibrem o mercado.

Além disso, seria inviável cada Estado, o Distrito Federal e cada Município ter uma lei estabelecendo normas tributárias indutoras. Sobre isso, Hamilton Diaz de Souza: 
•• Tributação, direitos fundamentais e desenvolvimento

De fato, se cada Estado ou Município, tendo em vista interesse dos que atuam em seus territórios, tivesse competência para criar tributação diferenciada para determinados setores, a discriminação de rendas tributárias e as normas gerais que lhe dão consistência poderiam ser seriamente afetadas. Imaginem-se, a propósito, regimes especiais em matéria de ISS ou até de ICMS introduzidos pelas legislações locais sob a alegação de evitar problemas concorrenciais. Isso inviabilizaria o trato uniforme dessas questôes no território nacional, prejudicando a lógica interna do sistema e possibilitando o surgimento de inúmeros conflitos federativos, sobretudo quando as operações realizadas repercutem em mais de um território. (Apud BRAZUNA, 2009, p. 115).

Ademais, seria a primeira vez em que a Constituição Federal requereria edição de lei complementar para os Municípios para tratar de algo que é de sua competência.

- $\quad 3^{\mathbf{a}}$ interpretação: $\mathrm{O}$ Congresso Nacional, mediante lei complementar, irá fixar parâmetros para que os Estados, o Distrito Federal e os Municípios elaborem suas próprias leis fixando os critérios especiais de tributação. O mesmo poderá ser feito pela União em relação aos seus tributos, por meio de lei ordinária e independente da criação da lei complementar.

- Considerações acerca da $3^{\mathbf{a}}$ interpretação: Podemos entender que essa interpretação iria contra a ideia de que o artigo seria uma outorga de competência ao legislador, que poderá ele próprio estabelecer os critérios especiais de tributação, necessários à norma tributária indutora. Também é incompatível com a competência material da União na defesa da concorrência, pois nesta hipótese, os Estados, o Distrito Federal e os Municípios poderão intervir nesta seara. Embora a interferência seja feita por parâmetros definidos em lei complementar, estaríamos na mesma situação de ter uma lei para cada estado, Distrito Federal e cada Município estabelecendo normas tributárias indutoras para prevenir distúrbios concorrenciais, além das normas indutoras editadas pela União.

- $\quad 4^{\mathbf{a}}$ interpretação: Através de lei complementar, o Congresso Nacional poderá fixar os critérios especiais de tributação somente aos tributos da União. O ente ainda poderá utilizar outros meios para a defesa da livre concorrência por meio de lei ordinária.

- Considerações acerca da $4^{\mathbf{a}}$ interpretação: Essa interpretação possui coerência com a competência da União para prevenir e reprimir desequilíbrios concorrenciais, existindo outorga de competência para instituir normas tributárias indutoras, sem afastar a possibilidade de a União utilizar outros instrumentos para intervir na economia, que seria por meio 
da lei ordinária federal. Sem mencionar que tal interpretação não permitiria que os outros entes possuíssem normas tributárias diferenciadas usando como fundamento o artigo 146-A, o que poderia fomentar uma intensificação na guerra fiscal. Ao instituir que a norma a ser utilizada seria a lei complementar, o Constituinte Derivado foi cuidadoso, uma vez que para aprová-la, é necessário quórum qualificado na Câmara dos Deputados e no Senado, o que significaria que haveria muito mais discussões e ponderações acerca de sua aprovação. Portanto, a quarta interpretação seria a mais adequada, pois daria a possibilidade de os Poderes Legislativo e Executivo terem uma maior reflexão acerca das normas tributárias indutoras, além de manter a centralização na União do poder de intervir na prevenção dos distúrbios concorrenciais ocorridos em território nacional.

\subsection{A consagração do princípio da neutralidade tributária}

Com fundamentação na leitura das obras de José Luís Ribeiro Brazuna, Rodrigo Maito da Silveira, Hamilton Dias de Souza e Misabel Abreu Machado Derzi, podemos afirmar que o artigo 146-A foi responsável por explicitar na Constituição Federal o princípio da neutralidade tributária, também funcionando como uma limitação ao poder de tributar, o que significa dizer que a função estatal de arrecadação não pode provocar desequilíbrios concorrenciais. A neutralidade tributária está correlacionada com a livre concorrência e vai funcionar como uma forma de restringir ações que façam com que os tributos se tornem danosos à concorrência, seja em menor ou maior grau, conforme discutimos no capítulo 1 deste trabalho. A existência desse princípio vai ao encontro da ideia já explicitada neste capítulo de que tributos não são economicamente neutros e somente com o princípio da neutralidade tributária seria possível garantir a concretização da livre concorrência, pois o tributo por si só não é capaz de fazê-lo.

Podemos concluir esse capítulo entendendo que o artigo 146-A possui dois aspectos dominantes ${ }^{35}$ :

1. Positivo: Autoriza a utilização de critérios especiais de tributação para prevenir desequilíbrios na concorrência, pois assim foi permitida a modificação dos elementos da norma tributária em prol de um objetivo específico.

BRAZUNA, José Luis Ribeiro. Op. cit., p. 101. 
•• Tributação, direitos fundamentais e desenvolvimento

2. Negativo: Funciona como uma limitação ao poder de tributar, no caso, a neutralidade tributária.

É importante, por fim, mencionar a necessidade de se ponderar os princípios no momento da criação da norma indutora e sua utilização, principalmente no que se refere à neutralidade tributária, a estrita legalidade e a irretroatividade da lei tributária, principalmente por conta do caráter instrumental que a livre concorrência possui. Outrossim, vamos analisar os projetos de lei complementar que visam regulamentar o disposto na norma constitucional, de tal forma que possamos entender como funcionaria, ao menos em tese, esse reequilíbrio da concorrência.

\section{OS PROJETOS DE LEI COMPLEMENTAR}

Conforme estudamos nos capítulos anteriores, o artigo 146-A da CRFB/88 tem a proposta de remediar distúrbios na concorrência causados pela tributação, por meio de critérios especiais na norma de incidência tributária. Esses critérios serão fixados pela lei complementar, a ser editada pelo legislador infraconstitucional. Até o presente momento, dois projetos de lei já foram propostos, em anos diferentes, com o objetivo de regulamentar o artigo 146-A. Vamos analisar nos tópicos seguintes os pontos que esses projetos de lei abordaram.

\subsection{Projeto de Lei Complementar n. 121/2011}

A justificativa do projeto $^{36}$ é instituir um mecanismo, por meio da tributação, que possa prevenir os distúrbios concorrenciais e criar um ambiente de livre funcionamento dos mercados de bens e serviços. Visa combater dois problemas: uma empresa ou um grupo de empresas que domine um mercado e distorçôes concorrenciais causadas pela própria tributação. Para poder combater os problemas, serão fixados critérios especiais de tributação, de tal forma que o equilíbrio concorrencial retorne.

O projeto de lei apresenta um ponto que os autores não concordam: propõe-se combater também distúrbios concorrenciais causados pelo monopólio de uma empresa ou grupo de empresas, o que se caracteriza como prática abusiva do

BRASIL. Projeto de Lei Complementar n. 121/2011. Brasília, Distrito Federal: Câmara dos Deputados, 2011. Disponível em: <http://www.camara.gov.br/proposicoesWeb/prop_mostra rintegra? codteor $=952353 \&$ filename $=P L P+121 / 2011>$. 
agente econômico. Isso significa que o projeto de lei não se limita a remediar desequilíbrios concorrenciais causados pelo próprio Estado quando exerce seu poder de tributar, mas se estende a atos causados pelos próprios agentes atuantes no mercado.

\subsubsection{Do desequilíbrio da concorrência}

O projeto de lei preocupou-se em definir quais são as situações que causam desequilíbrios na concorrência, que são:

a) Bens ou serviços que possuam dominância de mercado de tal forma que causem, por si só ou através de exercício abusivo, lesão irreparável ou de difícil reparação no mercado econômico.

b) Inadimplência no cumprimento de obrigações tributária, de forma isolada e sistemática, no caso de tributos que incidem sobre bens ou serviços, incluindo aqueles de competência estadual e municipal, e que representem significativa parcela na estrutura de custos. Nesse caso, o Poder Executivo irá elaborar e divulgar uma lista dos bens e serviços em que os ônus dos impostos que incidem neles representem uma parcela significativa dos custos gerais do contribuinte.

c) Importação e exportação de bens ou serviços que (1) por conta das características físicas do bem ou quantidades envolvidas na operação, cause dificuldades a mais ao controle aduaneiro e risco ao mercado relevante constituído por agentes econômicos estabelecidos no território nacional, e que (2) seja permitido o subfaturamento ou superfaturamento do valor da operação, por conta de sua procedência, destino ou outra característi$\mathrm{ca}$, ou fraudes à legislação que verse sobre origem e direito antidumping e compensatórios, com a comprovação de um devido processo administrativo prévio.

d) Concessão feita de forma irregular de incentivo fiscal à empresa ou grupo econômico ou autuações da administração tributária que estejam em desacordo com a CRFB/88 e a Lei n. 5.172/66, de modo que conceda privilégios à empresa ou ao grupo econômico. $\mathrm{O} \$ 2^{\circ}$ do artigo $2^{\circ}$ do Projeto de Lei define que a concessão irregular de incentivo fiscal é aquela em desacordo com os artigos $150, \$ 6^{\circ}, 155, \$ 2^{\circ}$, XII, “g”, e $\$ 6^{\circ}, \mathrm{I}$, $156, \$ 3^{\circ}$, I e III, da CRFB/88 e o artigo 88 da ADCT, e a LC 24/75. 
-. Tributação, direitos fundamentais e desenvolvimento

Sobre o item "d", a concessão de incentivo de maneira irregular é um desequilíbrio causado pelo próprio agente governamental e que causa guerra fiscal, uma vez que se trata de um favorecimento legal irregular dado a uma empresa x ou y. É o grande foco da luta contra o desequilíbrio na concorrência e de difícil prevenção, já que na maioria dos casos envolve o ICMS, um tributo indireto de competência estadual. O Projeto de Lei propõe que, no caso de incentivo fiscal concedido de forma irregular, o Senado poderá substituir a CIDE pela autorização para que os Estados que estejam sendo prejudicados efetuem a glosa de créditos provenientes do incentivo inconstitucional. A glosa será definida pelo CONFAZ, com quórum de maioria absoluta, participando pelo menos um Estado de cada região. Essa proposta visa recompor os cofres das entidades da Federação que foram lesadas por conta da guerra fiscal e restabelece o equilíbrio concorrencial.

O projeto de lei também prevê que a lei poderá estender esse rol de situações que causam desequilíbrio na concorrência, desde que sejam potencialmente prejudiciais ao mercado no sentido concorrencial. Além do rol de situações e atitudes que causem distúrbios na concorrência, o projeto apresenta um rol de situaçôes que não se caracterizam como provocadoras de distúrbios na concorrência:

a) Quando o agente econômico conquista o mercado de maneira natural por oferecer um serviço mais eficiente que seus concorrentes.

b) Concessão regular de incentivo fiscal.

c) Bens e serviços que tenham dominância relevante no mercado, nos casos em que a magnitude dos ganhos com economia de escola, inviabilize ou dificulte de forma significativa o aumento no número de fornecedores ou prestadores, por culpa da própria característica do mercado.

d) Outras razões de ordem econômica que justifique a dominância no mercado.

\subsubsection{Dos critérios especiais de tributação}

$\mathrm{O}$ artigo $4^{\circ}$ do projeto de lei encarregou-se de estabelecer quais são os critérios especiais de tributação, pois, num primeiro momento, o conceito desses critérios é bastante abstrato e é necessário observar como o legislador decidiu estabelecer essa tributação diferenciada que visa reequilibrar a concorrência. A proposta oferecida pelo projeto foi a instituição de uma Contribuição de Intervenção no Domínio Econômico (CIDE), que nada mais é que um tributo destinado a funcionar como instrumento de atuação da União no domínio econômico, finan- 
ciando custos e encargos que sejam pertinentes. Importante ressaltar que a cobrança da CIDE como forma de remediar problemas no mercado apenas será feita enquanto persistirem os desequilíbrios. Após cessarem, a cobrança da CIDE deverá acabar também.

A incidência da CIDE poderá ocorrer:

a) Sobre bens e serviços ou sobre lucratividade obtida com a produção, comercialização ou prestação desses bens ou serviços.

b) Sobre uma determinada empresa ou grupos de empresas, quando se tratar dos casos em que (1) os bens ou serviços possuam dominância de mercado de tal forma que cause, por si só ou através de exercício abusivo, lesão irreparável ou de difícil reparação no mercado econômico, ou em que (2) a concessão de forma irregular de incentivo fiscal a empresa ou grupo econômico ou autuações da administração tributária esteja em desacordo com a CRFB/88 e a Lei n. 5.172/66, de modo que conceda privilégios à empresa ou ao grupo econômico. $\mathrm{O} \$ 2^{\circ}$ do artigo $2^{\circ}$ do Projeto de Lei define que a concessão irregular de incentivo fiscal é aquela em desacordo com os artigos $150, \$ 6^{\circ}, 155, \$ 2^{\circ}$, XII, “g”, e $\$ 6^{\circ}, \mathrm{I}$, $156, \$ 3^{\circ}$, I e III, da CRFB/88 e o artigo 88 da ADCT, e a LC 24/75.

c) Com alíquotas ad valorem ou específicas, fixas ou variáveis.

A CIDE também pode estabelecer reduções, não incidências ou isenções levando em conta preços praticados ou quantidades ofertadas no mercado. Deverá também o fato gerador da CIDE estabelecer parâmetros objetivos para a delimitação do distúrbio da concorrência que objetiva evitar, cessar ou mitigar. No momento em que cessar ou mitigar o distúrbio concorrencial, com base nos parâmetros objetivos acima mencionados, a lei poderá suspender ou isentar o pagamento da contribuição. Se caso a situação de desequilíbrio concorrencial voltar a ocorrer, a CIDE será novamente cobrada com os respectivos acréscimos legais, que só deixará de ser cobrada quando novamente o cenário concorrencial ficar equilibrado.

Surge uma questão quando se fala de tributo: as receitas que serão arrecadadas através da CIDE, qual será a destinação delas? O projeto de lei também se preocupou em definir onde essas receitas serão aplicadas, que será em:

a) Obras ou infraestruturas que agilizem a circulação de bens e proporcionem facilidades à prestação de serviços. 
•• Tributação, direitos fundamentais e desenvolvimento

b) Ações relacionadas ao financiamento de empresas de pequeno e médio porte, à concessão de subsídios financeiros e incentivos que se destinem a aumentar a oferta ou a diminuição da concentração de mercado de bem ou serviço ou às despesas feitas pelos órgãos públicos para aplicar os critérios especiais de tributação e na defesa concorrência.

c) Outras atividades que sejam direcionadas para prevenir a ocorrência de distúrbios na concorrência e fomentar a competitividade entre as empresas estabelecidas no país, vedado empregar essa receita no financiamento de despesas correntes.

\subsubsection{Outras medidas do Projeto de Lei n. 121/2011}

Além do estabelecimento dos critérios especiais de tributação como forma de remediar os desequilíbrios na concorrência, o projeto estabeleceu regimes especiais de controle, o que significa dizer que a lei fixará parâmetros objetivos na avaliação da possibilidade de ocorrerem anomalias no mercado econômico, bem como deverá ocorrer sua cessação. Nesses casos, o regime especial poderá obrigar uma empresa ou grupo de empresas a utilizar selo de controle, equipamentos de controle de produção ou nota fiscal eletrônica ou sistema público de escrituração digital (nos casos em que os contribuintes ainda não tenham sido obrigados a utiliza-los).

Em relação à cobrança do CADE, esta não ficou exclusivamente para o Fisco, pois os elaboradores do projeto entenderam que o órgão estaria mais preocupado em realizar arrecadação de receita do que em promover o bom funcionamento dos mercados. Por consequência desse pensamento, o projeto deixou a verificação do risco de distúrbio na concorrência, bem como sua cessação, às autarquias federais que trabalham pela defesa da concorrência.

Ademais, será possível a instituição de um regime especial de controle para um determinado contribuinte ou um grupo de contribuintes que não estejam cumprindo com suas obrigações. Isso pode significar interdição do estabelecimento e baixa compulsória no CNPJ da empresa que esteja sonegando os impostos, ou seja, inadimplente com suas obrigaçōes tributárias. Na própria justificativa do projeto de lei, levanta-se a questão de essas medidas de controle serem uma possível agressão ao livre exercício profissional, mas contra argumentam apontando a leitura do acórdão da Ação Cautelar 1.657-6, RJ. Nesse acórdão, o STF entendeu como legítima uma interdição de estabelecimento produtor de cigarro que deixava de 
recolher IPI, de maneira sistemática e isolada, uma vez que, ao sonegar, essa conduta do contribuinte caracterizava-se como uma violação ao princípio da livre concorrência. Quando se tratar de bens ou serviços importados, o regime especial poderá exigir que essas circulações sejam feitas através de porto, aeroporto, ponto de fronteira ou recinto alfandegado especialmente equipado para prevenir situações de risco nos casos de importação em que (1) por conta das características físicas do bem ou quantidades envolvidas na operação, cause dificuldades a mais ao controle aduaneiro e risco ao mercado relevante constituído por agentes econômicos estabelecidos no território nacional, e em que (2) seja permitido o subfaturamento ou superfaturamento do valor da operação, por conta de sua procedência, destino ou outra característica, ou fraudes à legislação que verse sobre origem e direito antidumping e compensatórios, com a comprovação de um devido processo administrativo prévio. Também terá fixação, por meio de lei, da distância máxima entre o ponto de ingresso ou saída do bem, e o local especial determinado pela autoridade aduaneira.

Sobre as operações de importação e exportação que, por conta de suas características especiais, possam envolver um grande risco ao mercado nacional, temos o caso da importação de peças de vestuário. Um container pode transportar mercadorias em volume que equivalem a meses e meses de produção local de um determinado local no território brasileiro, que muitas vezes ingressa mediante fraude às regras de origem e desembaraçada com impostos aduaneiros incidindo sobre valores inferiores ao do mercado nacional. $\mathrm{O}$ mesmo pode ocorrer em caso de importação de produtos em informática, princípios ativos de medicamentos e outros insumos que possuam alto valor agregado. Se a operação for feita de forma irregular, estará caracterizada a concorrência desleal, ou seja, desequilíbrio na concorrência. Outro exemplo dessas operações é a exportação de cigarros aos países vizinhos que retornam ao território nacional com preços mais baixos, uma vez que ocorre a desoneração do tributo no momento da saída da mercadoria do território nacional e também no momento em que reingressa.

Como dito anteriormente, será através de formas de controle aduaneiro que lidem com os desembaraços mais delicados como esses que será prevenido ou remediado o desequilíbrio concorrencial, porque uma vez que as mercadorias estão em situação de vantagem no mercado comercial, também existirá uma vantagem para o agente que está colocando essas mercadorias em circulação. 
•• Tributação, direitos fundamentais e desenvolvimento

\subsection{O Projeto de Lei n. 161 de 201337}

\subsubsection{Competência para instituir os critérios especiais de tributação}

Discutimos no capítulo 2 sobre quem teria competência para instituir os critérios especiais de tributação, e o projeto de lei, em seu primeiro artigo, já definiu como funcionaria. Autorizou todos os entes - União, Estados, Distrito Federal e Municípios - adotarem, por meio de lei específica, os critérios especiais de tributação que foram disciplinados pela Lei Complementar. A União não teria sua competência suplementar afastada para estabelecer normas tributárias que objetivam prevenir distúrbios concorrenciais.

Podemos perceber que esse artigo vai ao encontro com a $3^{\mathrm{a}}$ interpretação dada ao artigo art. 146-A, CRFB/88, que entende que a Lei Complementar vai estabelecer os parâmetros dessa tributação especial para que os outros entes - Estados, Distrito Federal e Municípios - possam estabelecer seus critérios especiais mediante lei específica. Esse artigo vai de encontro com a interpretação que adotamos para esse trabalho, que seria a adoção de critérios especiais de tributação em Lei Complementar aprovada pelo Congresso Nacional. Desta maneira, não seria possível que existissem critérios diferenciados para cada ente e não fomentaria a guerra fiscal.

\subsubsection{Critérios especiais de tributação}

O próprio Projeto de Lei definiu esse critério especial como uma forma diferenciada de tributação, relativo ao regime que se aplica aos contribuintes no geral, para cumprimento das obrigaçóes principais ou acessórias.

Ademais, o projeto também definiu quais são esses critérios especiais:

a) Antecipação de fato gerador, inclusive mediante substituição tributária: podemos entender a substituição tributária como uma das formas de responsabilidade em que uma terceira pessoa (substituto) ocupa o lugar do contribuinte, assumindo a obrigação tributária antes da ocorrência do fato gerador do tributo. Desde o início, o substituto tributário irá arcar com o pagamento do tributo, fazendo com que o contribuinte não tenha que adimplir tal obrigação.

BRASIL. Projeto de Lei Complementar n. 161 de 2013. Brasília, Distrito Federal: Senado Federal, 2013. Disponível em: <http://legis.senado.leg.br/mateweb/arquivos/mate-pdf/127222.pdf>. 
O art. 146-A da Constituição Federal e o Princípio da Neutralidade Tributária ••

b) Concentração da incidência do tributo em determinada fase do ciclo econômico.

c) Determinação de valores mínimos na determinação da base de cálculo com o intuito de se utilizar a alíquota ad valorem, usando como parâmetro o preço normal do produto ou serviço numa situação de livre concorrência.

d) Alíquota específica, usando como base a unidade de medida adotada.

e) Instalação obrigatória de medidores de peso, volume ou vazão.

f) Regime especial de fiscalização e apuração de tributos.

g) Suspensão ou cassação do registro especial de funcionamento das empresas cujas atividades estão sujeitas à autorização governamental.

Os critérios especiais de tributação, no caso dessa lei complementar, serão (1) instituídos por meio de lei específica do ente da Federação que tem competência para instituir o tributo, poderão ser aplicados de maneira conjunta, (2) poderão também ser aplicados sem necessitar da observância dos requisitos estabelecidos pela lei complementar proposta e autorizada pela Constituição Federal ou por lei complementar específica, e (3) deverão ser objeto de acordo específico quando se tratar de tributos que incidem sobre operaçôes ou prestaçóes que ultrapassem os territórios das unidades federativas instituidoras.

Da mesma forma que o projeto de lei complementar n. 121 de 2011, esse projeto entendeu que os critérios especiais de tributação irão vigorar enquanto o distúrbio concorrencial ainda persistir, observando as seguintes ressalvas:

a) Para instituir o critério especial, deve existir motivação expressa que mostre que existe uma situação onde está caracterizado o desequilíbrio concorrencial. Noutro artigo, definiu-se o que significa desequilíbrio concorrencial: uma anomalia no funcionamento do mercado que poderá causar problemas no mecanismo de formação de preço, na livre concorrência e na liberdade de iniciativa, causados por atos de agente econômico e que impossibilitem o não recolhimento de tributo suportado pelos demais contribuintes.

b) Em caso de certos setores da atividade econômica potencialmente mais vulneráveis a distúrbios concorrenciais, o prazo de vigência dos critérios especiais poderá ser indeterminado. Esses setores potencialmente mais vulneráveis são aqueles em que: (1) a tributação é fator relevante para a 
-• Tributação, direitos fundamentais e desenvolvimento

composição de preços de produtos ou serviços, de modo que não recolher os tributos pode exercer influência preponderante sobre o respectivo comportamento concorrencial, (2) as condiçôes estruturais do mercado dificultam o controle eficiente dos diferentes meios de evasão fiscal como causa recorrente de distúrbios concorrenciais e (3) a vantagem competitiva proporcionada pelo não recolhimento do tributo conduza ou reforce situações de posição dominante na estrutura do mercado.

Por fim, o projeto retira do campo de aplicação dos critérios especiais de tributação os tributos que incidem sobre a renda, o lucro, a movimentação financeira ou o patrimônio, pois entende que não seriam capazes de causar distúrbios concorrenciais, uma vez que geralmente quem suporta a carga tributária é o próprio sujeito passivo. Esse sistema de combate às condutas que podem ser lesivas à concorrência está voltado para os tributos que possuem repercussão maior durante o ciclo de circulação de mercadorias e serviços, como é o caso do PIS, Cofins e ICMS. Todavia, se ocorrer de um tributo direto causar desequilíbrio concorrencial, a maneira de combate é por meio de mecanismos de tributação peculiares, que podem ser veiculados por lei ordinária no que tange os tributos federais, com base na competência suplementar da União.

\subsubsection{Da configuração do desequilíbrio concorrencial}

O projeto de lei também insere nessa prevenção dos desequilíbrios concorrenciais os órgãos de defesa da concorrência. Esses órgãos terão o trabalho de examinar quais são os efeitos na concorrência que as práticas tributárias poderão ter. Caso constatem que alguma prática tributária pode causar desequilíbrio concorrencial, a administração tributária do ente em questão deve ser comunicada para que tome as medidas cabíveis. Esses desequilíbrios concorrenciais estão sujeitos, conforme o projeto, ao controle do Sistema Brasileiro de Defesa da Concorrência. Os órgãos poderão ensejar a aplicação de penalidades específicas para a repressão ao abuso de poder econômico, bem como identificar quais são os desequilíbrios concorrenciais e investigar os motivos. Portanto ficam os órgãos da SBDC responsáveis pela prevenção e repressão de práticas que violem a ordem econômica, sem, no entanto, interferir na aplicação da tributação, que é função das autoridades fiscais.

Contudo, existem decisōes do CADE que atribuem às administrações tributárias a análise das questóes tributárias que prejudiquem a livre concorrência. Por 
isso, houve a inclusão do artigo no projeto de lei que prevê que serão os órgãos da SBDC que irão avaliar e combater os distúrbios concorrenciais, observando obviamente suas competências para não violar as da administração tributária. Concluímos que, além de poderem utilizar a tributação - por meio de seus critérios especiais - para reequilibrar uma situação de problema com a concorrência, as empresas também poderão recorrer aos órgãos de defesa da concorrência, de forma que as providências necessárias sejam tomadas para cessar as causas que estejam dando ensejo ao distúrbio concorrencial.

\subsubsection{Da justificação do Projeto de Lei}

$\mathrm{Na}$ justificação do projeto, levanta-se a questão de os critérios especiais de tributação servirem para concretizar o aspecto positivo da neutralidade tributária, qual seja, impor medidas que tornem a carga tributária eficaz. Isso importa em assegurar a uniformidade da carga tributária por meio de uma tributação diferenciada para alguns contribuintes com o objetivo de igualar a carga tributária e, consequentemente, prevenir o desequilíbrio concorrencial. É utilizar a tributação na sua forma fiscal e extrafiscal para promover dois objetivos: a isonomia e a livre concorrência entre as partes.

Também foi levantada a questão que anteriormente discutimos, de que os critérios especiais de tributação não se tratam de instituição de novos tributos ou aumento dos que já são previstos, pois se assim fossem, estariam desviando de sua finalidade. A aplicação desses critérios especiais de tributação que de alguma forma alterem a forma de cálculo do tributo deve ser fundamentada com dados reais do mercado. A utilização da lei complementar como instrumento para instituir critérios especiais de tributação também se justifica, como havíamos também discutido nesse trabalho, já que sem ela, cada ente poderia criar seus próprios critérios especiais de tributação e seriam 26 leis estaduais, uma lei distrital e 5.500 leis municipais com critérios diferentes para remediar desequilíbrios concorrenciais. Não seria nem um pouco uniforme, causaria insegurança jurídica e violação do princípio da isonomia. Ressalvas para os tributos de competência da União, que não estariam dentro desse quadro problemático, já que devem ser uniformes. Todavia, a União deverá observar a lei complementar no que tange esses tributos federais, mas também poderá editar normas suplementares para versar sobre temas que sejam de seu interesse e não tenham sido regulados pela lei nacional. Com a edição da lei complementar, os entes e a administração tributária terão parâmetros concretos sobre 
•• Tributação, direitos fundamentais e desenvolvimento

os quais pautarão suas ações para prevenir ou remediar distúrbios na concorrência. Do outro lado, o contribuinte estará protegido pela segurança jurídica de saber quais são os parâmetros que a administração tributária poderá se valer para tomar suas ações.

Por fim, o projeto de lei recepcionou as normas tributárias editadas pela União antes da edição dessa lei complementar que tenham o condão de prevenir os distúrbios concorrenciais tributários, o que significa dizer que elas não poderão sua validade com o possível advento dessa lei complementar. Obviamente que, após a entrada em vigência da lei complementar, as novas leis federais deverão estar em conformidade com as disposiçôes da lei nacional, sendo revogados os preceitos que forem contrários. É mister que o ordenamento jurídico esteja harmônico e coeso de forma que não ocasione insegurança jurídica aos seus tutelados, especialmente na seara tributária, onde a legalidade é preceito de muito valor.

\section{CONCLUSÃO}

Como pudemos observar no estudo desse trabalho, o artigo 146-A da CRFB/88 configura-se como uma norma constitucional de grande importância para a defesa da livre concorrência de atos tomados pelo Estado no exercício de seu poder de tributar. A maioria dos doutrinadores entende que se trata de uma norma que explicita na ordem constitucional o princípio da neutralidade tributária. De início, conforme expusemos, faz-se mister entender que a tributação não pode ser, por si só, neutra, já que entender dessa forma seria utopia. Não existe um sistema tributário que seja perfeito, que não cause impacto na conduta dos contribuintes ou que não tenha o mínimo de influência econômica, independente se for um tributo de cunho fiscal ou extrafiscal. A ideia por trás da neutralidade tributária é que a conduta do Estado, no momento em que vai exercer seu poder de tributar, não deve causar distúrbios na concorrência, prezando pela igualdade entre os agentes atuantes no mercado. Os princípios da igualdade e da neutralidade tributária parecem possuir quase uma mesma definição, o que demanda a existência de algum critério que realize a diferenciação dos conceitos. Os autores apontam a livre concorrência como esse critério, já que a igualdade está ligada ao tratamento igualitário - inclusive na seara tributária - de quem se encontra em situação de igualdade, enquanto a neutralidade tributária lida com o tratamento igualitário dispensado pelo Estado no momento de exercer seu poder de tributar de forma que não afete a livre concorrência. 
Ademais, o referido artigo prevê a criação de uma lei complementar que estabelecerá critérios especiais de tributação com o condão de prevenir distúrbios concorrenciais. Importante sempre mencionar que a criação de critérios especiais de tributação não se trata da criação de um novo tributo que vise reequilibrar o mercado concorrencial, mas sim a modificação da regra matriz de incidência dos próprios impostos já instituídos de forma que o agente econômico que se encontre numa situação de concorrência irregular possa voltar a estar em igualdade perante os outros agentes. Essa modificação incidirá, basicamente, na estrutura da norma de incidência tributária, o que poderá acarretar na mudança do contribuinte, da alíquota, da base de cálculo etc. Os distúrbios concorrenciais que o artigo alude são aqueles provocados pelo poder de tributar do Estado e não aqueles provocados por um ato abusivo de um agente econômico ou por uma falha estrutural do mercado. Esses últimos atos que causam distúrbios concorrenciais serão remediados por meio do Sistema Brasileiro de Defesa da Concorrência e não pelo artigo 146-A. Este artigo preocupa-se com uma questão tributária e propõe a solução por meio de critérios especiais que incidem na própria norma tributária.

Os projetos de lei complementar de 2011 e 2013 preocuparam-se em suprir a lacuna legislativa causada pelo artigo 146-A, CRFB/88 e, consequentemente, estabelecer os critérios especiais de tributação que teriam o condão de prevenir distúrbios concorrenciais, o que, por sua vez, funcionaria como defesa da livre concorrência. Cada um dos projetos trouxe seus critérios especiais de tributação, um através da instituição de Contribuição sobre a Intervenção do Domínio Econômico, que funcionará como um instrumento da União para poder intervir no mercado econômico e o outro, através da modificação da regra matriz de incidência e outras formas de controle que podem ser feitos por meio da administração tributária. Ressalvas para o projeto de lei n. 161 de 2013 que instituiu como competência dos órgãos da SBDC a fiscalização de situações que possa estar ocorrendo desequilíbrios concorrenciais, sem prejuízo da competência os órgãos da administração tributária de tratar de questôes que envolvam a tributação. Portanto, quem irá monitorar e informar aos órgãos da administração tributária situações em que o princípio da livre concorrência esteja sendo violado é os órgãos do SBDC. Trata-se de uma união de esforços para a promoção da livre concorrência, violada por uma tributação que não obedeceu aos princípios do Direito Tributário.

Não há como negar a necessidade de os legisladores debruçarem-se novamente em cima desse assunto, de forma que esse artigo constitucional tenha sua devida 
•• Tributação, direitos fundamentais e desenvolvimento

regulamentação. $\mathrm{O}$ primeiro ponto a se ressaltar é que não é desejável a um ordenamento jurídico coeso e uno que ele possua lacunas na regulamentação de artigos constitucionais, porque isso significa que o ordenamento não está tutelando todos os direitos e objetivos propostos pela Carta Magna. O segundo ponto é que o artigo visa à defesa da livre concorrência de uma tributação que possa lesioná-la e esta concepção, dentro da defesa dos princípios da Ordem Econômica, é deveras importante para que exista um funcionamento sadio das relações comerciais. O terceiro ponto é que, com a defesa da livre concorrência dentro do campo desse artigo, também teremos a promoção de uma tributação justa, traduzida pelo princípio da neutralidade tributária. A defesa da neutralidade tributária envolve diversos outros princípios constitucionais e também o próprio sistema tributário: na medida em que a tributação prejudica um contribuinte, diversos princípios tributários são violados e cria um ambiente de insegurança jurídica. No caso do mercado, causa problema de tratamento isonômico entre os agentes e, por consequência, desequilibra a concorrência entre eles. Este presente trabalho preocupou-se em estudar esse tema porque a tributação não deve ser utilizada para desequilibrar a livre concorrência e a presença de uma lacuna legislativa apresenta um problema para a economia e o sistema jurídico como um todo. De alguma forma, procuramos ponderar os aspectos importantes nessa discussão de forma que uma atenção maior seja dada ao assunto.

\section{REFERÊECIAS}

AMARO, Luciano. Direito tributário brasileiro. 19. ed. São Paulo: Saraiva, 2013.

BRASIL. Proposta de Emenda Constitucional 41 de 2003. Brasília: Distrito Federal. Disponível em: <http://www.camara.gov.br/proposicoesWeb/prop_mostrarintegra?codte or $=129816 \&$ filename $=\mathrm{PEC}+41 / 2003>$. Acesso em: 18 maio 2015.

BRASIL. Projeto de Lei Complementar n. 121/2011. Brasília, Distrito Federal: Câmara dos Deputados, 2011. Disponível em: <http://www.camara.gov.br/proposicoesWeb/prop_most rarintegra? codteor=952353\&filename $=$ PLP+121/2011>. Acesso em: mar. 2016.

BRASIL. Projeto de Lei Complementar n. 161 de 2013. Brasília, Distrito Federal: Senado Federal, 2013. Disponível em: <http://legis.senado.leg.br/mateweb/arquivos/mate-pdf/ 127222.pdf>. Acesso em: mar. 2016.

BRAZUNA, José Luis Ribeiro. Defesa da livre concorrência e tributação - à luz do artigo 146-A da Constituição. São Paulo, Universidade de São Paulo, 2009. Tese (Mestrado em Direito) - Programa de Mestrado em Direito Financeiro, Econômico e Tributário, Universidade de São Paulo, São Paulo, 2009. 
FORTES, Fellipe Cianca; BASSOLI, Marlene Kempfer. Análise econômica do Direito Tributário: livre iniciativa, livre concorrência e neutralidade fiscal. Scientia Iuris, Londrina, v. 14, p. 235-253, nov. 2010.

FRANÇA. Declaração dos Direitos do Homem e do Cidadão, 1776. Disponível em: <http:// pfdc.pgr.mpf.mp.br/atuacao-e-conteudos-de-apoio/legislacao/direitos-humanos/declar_ dir_homem_cidadao.pdf>. Acesso em: mar. 2016.

LIMA, Ricardo Seibel de Freitas. Livre concorrência e o dever de neutralidade tributária. Porto Alegre, Universidade Federal do Rio Grande do Sul, 2005. Tese (Mestrado em Direito) - Programa de Pós Graduação em Direito da Universidade Federal do Rio Grande do Sul, Porto Alegre, 2005.

MACHADO, Hugo de Brito. Lei complementar tributária. São Paulo: Malheiros, 2010.

NOGUEIRA, Vinícius Alberto Rossi. Direito tributário e livre concorrência: da interpretação e aplicação do artigo 146-A da Constituição Federal artigo 146-A da Constituição Federal. São Paulo, Universidade de São Paulo, 2014. Tese (Mestrado em Direito) - Programa de Mestrado em Direito Financeiro, Econômico e Tributário, Universidade de São Paulo, São Paulo, 2014. Disponível em: <http://www.teses.usp.br/ teses/disponiveis/2/2133/tde-21012015-084157/>. Acesso em: 30 jun. 2015.

OLIVEIRA, Alexandre Machado de. Imunidade tributária. Âmbito Jurídico, Rio Grande, XIII, n. 77, jun 2010. Disponível em: <http://www.ambitojuridico.com.br/site/index. php?n_link=revista_artigos_leitura\&artigo_id=7865>. Acesso em: mar. 2016.

ROTHMANN, Gerd Willi. Tributação, sonegação e livre concorrência. In: Ferraz, Roberto (Coord.). Princípios e limites da tributação 2. São Paulo: Quartier Latin, 2009.

SANTOS, Luiz Fernando Barboza dos. Sonegação fiscal e livre concorrência. XXXIX Congresso Nacional de Procuradores de Estado. Rio Grande do Norte, 2013.

SCHOUERI, Luís Eduardo. Livre concorrência e tributação. In: Grandes questôes atuais do direito tributário, $11^{\circ}$ volume. Coordenador: Valdir de Oliveira Rocha. São Paulo: Dialética, 2007.

SCHOUERI, Luís Eduardo. Normas tributárias indutoras e intervenção econômica. São Paulo: Forense, 2005.

SCHOUERI, Luís Eduardo. Tributação e Indução Econômica: os efeitos econômicos de um tributo como critério para sua constitucionalidade. In: FERRAZ, Roberto Catalano Botelho. Princípios e limites da tributação 2. São Paulo: Quartier Latin, 2009.

SILVEIRA, Rodrigo Maito da. Tributação e concorrência. São Paulo: Quartier Latin, 2011. v. IV (Série Doutrina Tributária).

TORRES, Ricardo Lobo. Interação entre princípios constitucionais tributários e princípios da ordem econômica. In: Ferraz, Roberto (Coord.). Princípios e limites da tributação 2 São Paulo: Quartier Latin, 2009. 
